\title{
Comparative study on the influence of silicon and selenium to mitigate arsenic induced stress by modulating TCA cycle, GABA and polyamine synthesis in rice seedlings
}

\section{Susmita Das}

University of Calcutta

Barsha Majumder

University of Calcutta

Asok Kumar Biswas ( $\nabla$ dr.asokbiswas25@gmail.com )

University of Calcutta

\section{Research Article}

Keywords: Arsenic, GABA, Polyamine, Respiration, Silicon, Selenium, Stress mitigation

Posted Date: July 8th, 2021

DOl: https://doi.org/10.21203/rs.3.rs-189429/v1

License: (c) (1) This work is licensed under a Creative Commons Attribution 4.0 International License. Read Full License

Version of Record: A version of this preprint was published at Ecotoxicology on February 5th, 2022. See the published version at https://doi.org/10.1007/s10646-022-02524-8. 


\section{Abstract}

Arsenic contamination of groundwater is a major concern for its use as drinking water and crop irrigation in many regions of the world. Arsenic is absorbed by rice plants from arsenic contaminated water during irrigation, hampers growth and agricultural productivity. The aim of the study was to mitigate the activity of TCA cycle, synthesis of $y$-aminobutyric acid (GABA) and polyamines (PAs) in rice (Oryza sativa L. cv. MTU-1010) seedlings under arsenate (As-V) stress [25 $\mu \mathrm{M}, 50 \mu \mathrm{M}$ and $75 \mu \mathrm{M}$ ] by silicon (Si) [2 mM] and selenium (Se) $[5 \mu \mathrm{M}]$ amendments, and to investigate which chemical was more potential to combat this threat. As $(\mathrm{V})$ application decreased the activities of tested respiratory enzymes while the levels of organic acids (OAs) were increased in the test seedlings. Co-application of Si and As(V) increased the activities of respiratory enzymes, consequently further increased accumulation of OAs that were more than Se with As(V) application in the test seedlings. GABA accumulation along with the activities of its regulatory enzymes were enhanced under $\mathrm{As}(\mathrm{V})$ stress. During joint application of $\mathrm{Si}$ and $\mathrm{As}(\mathrm{V})$ and $\mathrm{Se}$ and $\mathrm{As}(\mathrm{V})$ said parameters were decreased showing defensive role of these chemicals to resist As(V) toxicity in rice but amendment of Si was more potential than Se amendment resulted reduction of stress induced damage in the test seedlings. PAs trigger tolerance mechanism against stress in plants. PAs viz., Putrescine, spermidine and spermine were synthesized more during Si and Se amendments in $\mathrm{As}(\mathrm{V})$ contaminated rice seedlings to combat the effect of stress. Si amendment substantially modulated the toxic effects caused by $\mathrm{As}(\mathrm{V})$ over Se amendment in $\mathrm{As}(\mathrm{V})$ challenged test seedlings. Thus in future application Si enriched fertilizer will be beneficial than application of Se enriched fertilizer to grow rice plants with normal vigor in arsenic contaminated soil.

\section{Introduction}

The world is advancing in science and technology. However poor control is recurrently disturbing the ecosystem and environment of our green earth. Among others, the increasing volume of different heavy metals in groundwater is becoming a common cause of environmental and ecological toxicity across the globe, affecting agriculture and crop production in a large extend; these, in turn, further put the human food safety and health at risk. One common such carcinogenic metal is arsenic (As) which has overreached the tolerable limit $\left(>0.01 \mathrm{mg} \mathrm{L}^{-1}\right)$ in groundwater of many parts of the world, including Bangladesh (Das et al. 2009) and India especially West Bengal (Dey et al. 2014). The rice is extremely potent for As accumulation from soil due to its irrigation by As contaminated ground water. Arsenic damages several physiological and biochemical functions of plant cells related with enzymes and proteins that ultimately seizes plant growth (Meharg and Hartley-Whitaker, 2002). There are two important trace elements viz., silicon (Si) and selenium (Se), known to enhance tolerability in plants against various kinds of biotic and abiotic stresses (Hasanuzzaman et al. 2014). Si, a metalloid present in soil as silicic acid ranging from $0.1 \mathrm{mM}$ to $2 \mathrm{mM}$ concentrations (Bogdan et al. 2008). It is accumulated by crops including rice and exerts beneficial roles in growth, yield and productivity by elevating tolerability under abiotic and biotic stresses (Singh et al. 2011; Soundararajan et al. 2014; Adrees et al. 2015; Tripathi et al. 2016; Pontigo et al. 2017). In the study of Fleck et al. (2013), it was 
reported that Si supplementation enhanced the yield and productivity of rice grain cv. Selenio by reducing As concentration in the soil. They also stated that the application of Si alleviated As contents in rice straw, husk and flag leaf but elevated the levels of iron and phosphate in soil. Hussain et al. (2021) demonstrated that the yield as well as photosynthetic activity was increased by Si administration under shading environment in soybean. In the study of Ahmad et al. (2021), it was reported that joint application of Si and nitric oxide (NO) decreased As induced toxicity by reducing As accumulation and oxidative stress in Brassica juncea. Si administration also alleviated oxidative stress and ameliorated ascorbate-glutathione pathway in Brassica napus under Cd stress (Hasanuzzaman et al. 2017) and in Oryza sativa L. under As(V) stress (Das et al. 2018). Se is also present in soil ranging from 0.1 to $2 \mathrm{mg}$ $\mathrm{kg}^{-1}$ (Swaine, 1955). Se exhibits both positive and negative role in plants, it possess capability to enhance crop productivity by generating stress tolerance mechanisms under environmental stresses (Hasanuzzaman et al. 2020). In plants Se possesses effects to enhance tolerance against environmental stresses by promoting antioxidant defense system (Das et al. 2011; Zwolak and Zaporowska, 2012; Ulhassan et al. 2019a). In the report of Ulhassan et al. (2019b), it was also noted that Se plays double role in physicochemical aspects in Brassica napus like in lower dose $(25 \mu \mathrm{M})$ Se increased growth and photosynthesis but in higher dose $(50-100 \mu \mathrm{M})$, it reduced growth, biomass, nutrient uptake and also photosynthetic activities in Brassica napus.

Mitochondria possess the role as 'sensors' in plants during stress environment (He et al. 2015). Samikkannu et al. (2003) showed that, the enzyme pyruvate dehydrogenase (PDH) is the foremost target for As toxicity which ultimately results in oxidative damages in plant cells. Two consecutive oxidative decarboxylation steps occur in TCA cycle i.e. the production of 2-oxoglutaric acid or a-ketoglutaric acid from isocitric acid and eventually the production of succinyl Co-A with the synthesis of 2 molecules $\mathrm{NADH}$ on one hand and the liberation of 2 molecules $\mathrm{CO}_{2}$ on the other. Afterwards succinic acid is synthesized from succinyl Co-A and subsequently it is oxidized to produce fumaric acid by the activity of succinate dehydrogenase $(\mathrm{SDH})$ interlinked with the generation of ubiquinol $\left(\mathrm{UQH}_{2}\right)$ from ubiquinone (UQ). In the study of Quinlan et al. (2012), it was reported that if a non-competitive inhibitor viz., thenoyltrifluoroacetone (TIFA) restricts the activity of SDH, it may produce reactive oxygen species (ROS) in mammals', mitochondria. ROS are present in plants in very low level under control condition but the production of ROS is enhanced in plant cells during different environmental stressed conditions. Marino et al. (2012) demonstrated that the electron transport chain in plant chloroplast and mitochondria can also produce ROS due to the activity of NADPH oxidases under stress conditions. Plant mitochondria act a crucial part in ATP generation as well as in regulation of metabolic pathways of Krebs cycle intermediates (Nunes-Nesi et al. 2008). Beside these, plant mitochondria possess various kinds of cellular activities viz., maintain an equilibrium between nitrogen and carbon levels (Sienkiewicz-Porzucek et al. 2010), assist to improve photosynthetic activities (Nunes-Nesi et al. 2008), also help in physiological development of plants viz., germination of seeds and development of flowers and fruits (Sweetman et al. 2009; Centeno et al. 2011). 
$\gamma$-aminobutyric acid (GABA), a kind of amino acid is present in plants favours enhanced accumulation under environmental stresses. It is produced from glutamate by a decarboxylation reaction catalyzed by glutamate decarboxylase (GAD). In mitochondria, it is metabolized to succinic semialdehyde and finally to succinic acid by aminobutyrate oxoglutarate aminotransferase (GABA-T) and succinic semialdehyde dehydrogenase (SSADH) respectively (Bown and Shelp, 1997). Succinic acid is again fed into the TCA cycle. Thus, this pathway is known as GABA shunt. In plants, GABA shunt is involved in osmoregulation, nitrogen metabolism, cell signaling and balancing cytosolic pH etc. (Bouché and Fromm, 2004). The levels of GABA elevated under various abiotic stresses viz., in Nicotiana sy/vestris under salt stress (Akçay et al. 2012), in Sesamum indicum L. under salinity, drought and temperature stresses (Bor et al. 2009), in Agrostis stolonifera under heat stress (Li et al. 2016) and in Piper nigrum under polyethylene glycol (PEG) stress (Vijayakumari and Puthur, 2016).

Polyamines (PAs) are small organic molecules found in living beings of which three polyamines viz., putrescine (Put), spermidine (Spd) and spermine (Spm) are present in plants. Put is the precursor of Spd and Spm (Xu et al., 2009). These three PAs regulate the whole biosynthetic process in cell. PAs regulate various kinds of physiological activities in plants viz., germination of seeds, maintain stability of cell wall and cell membrane, development of different plant parts, leaf senescence, initiation of floral parts and its expansion, development and ripening of fruits and give responses under environmental stresses (Kusano et al. 2008). PAs cumulates under stressed environs viz., heavy metal stress, salt stress (Duan et al. 2008; Radhakrishnan and Lee, 2013), hypoxic condition, UV radiation, chilling environs (Cuevas et al. 2008), heat and drought stress (Yang et al. 2007; Groppa and Benavides, 2008). They also develop some adaptive features in plants that would help to defend against stress induced oxidative damages (Gupta et al. 2013). Among the three PAs, the level of Put was enhanced while the levels of Spd and Spm were declined in Vicia faba L. under hypoxic environment (Yang et al. 2013). Elevated accumulation of PAs regulates the expression of genes that control the antioxidant defense properties in transgenic tobacco indicating generation of stress tolerance activities (Wi et al. 2014). PAs also play an important role as free radical scavengers in plants (Edreva et al. 2007).

The purpose of this study was to investigate the protective role of Si and Se in modulating the toxic effects caused by $\mathrm{As}(\mathrm{V})$ on TCA cycle in terms of organic acid accumulation, activities of respiratory enzymes and its relation on GABA and PA accumulation in hydroponically grown rice (Oryza sativa L. cv. MTU-1010) seedlings under As $(V)$ stress. The differences were observed between treatments of $A s(V)+S i$ and $A s(V)+$ Se over only $A s(V)$ treated seedlings in terms of considered parameters and illustrated the role of $\mathrm{Si}$ and $\mathrm{Se}$ in mitigation of $\mathrm{As}(\mathrm{V})$ toxicity in rice seedlings.

\section{Material And Methods}

\subsection{Plant material and chemical treatments}

Rice (Oryza sativa L.) seeds, cv. MTU-1010, were surface sterilized with $5 \% \mathrm{NaOCl}$ solution and washed thoroughly with distilled $\mathrm{H}_{2} \mathrm{O}$. Fifty seeds for each treatment were spread over in petridishes $(11 \mathrm{~cm}$ in 
diameter) lined with filter papers containing water, incubated at $37^{\circ} \mathrm{C}$ for three days in dark for germination. The germinated seeds were transferred to petridishes lined with filter papers containing 25 $\mu \mathrm{M}, 50 \mu \mathrm{M}$ and $75 \mu \mathrm{M}$ sodium arsenate $\left(\mathrm{Na}_{2} \mathrm{HAsO}_{4} \cdot 7 \mathrm{H}_{2} \mathrm{O}\right.$; Loba-Chemie, India) solutions (w/v) with or without $2 \mathrm{mM}$ sodium silicate $\left(\mathrm{Na}_{2} \mathrm{SiO}_{3} \cdot 9 \mathrm{H}_{2} \mathrm{O}\right.$; Loba-Chemie, India) and $5 \mu \mathrm{M}$ sodium selenate $\left(\mathrm{Na}_{2} \mathrm{SeO}_{4}\right.$; Loba-Chemie, India) solution along with modified Hoagland solution ( $\mathrm{pH} \mathrm{6.5)} \mathrm{and} \mathrm{exposed} \mathrm{for} 18$ days (total 3 weeks) at $28^{\circ} \pm 2^{\circ} \mathrm{C}$ under $16 \mathrm{~h}$ photoperiod $\left(260 \mu \mathrm{mol} \mathrm{m}{ }^{-2} \mathrm{~s}^{-1} \mathrm{PFD}\right)$. We have standardize the desired concentrations of $\mathrm{As}(\mathrm{V})$, Si and Se after screening of several doses of $\mathrm{As}(\mathrm{V})$, Si and Se on the basis of growth data obtained. The concentrations of $\mathrm{As}(\mathrm{V})$ used viz., $25 \mu \mathrm{M} 50 \mu \mathrm{M}$ and $75 \mu \mathrm{M}$ were comparable to field and soil condition (Logoteta et al. 2009). $2 \mathrm{mM}$ Si and $5 \mu \mathrm{M}$ Se were chosen for mitigation of $\mathrm{As}(\mathrm{V})$ induced toxicity in rice seedlings. The control set was composed of only modified Hoagland solution (Hoagland and Arnon, 1950). In every alternate day, fresh solutions were added in each treatment with $\mathrm{pH}$ adjustment. Then the seedlings were harvested, root and shoot were separated for the following studies.

\subsection{Estimation of organic acids content 2.2.1. Pyruvic acid content}

Plant sample (both roots and shoots of rice cv. MTU-1010) of $1 \mathrm{~g}$ each was extracted in $5 \mathrm{ml} 0.2 \mathrm{M}$ sodium phosphate buffer $\left(\mathrm{pH} \mathrm{7.4)}\right.$ ) and centrifuged at $10,000 \mathrm{rpm}$ for $15 \mathrm{~min}$ at $4^{\circ} \mathrm{C}$. The supernatant was deproteinized with 5\% TCA and filtered. The filtrate was used for assay. Reaction mixture was comprised of $1 \mathrm{ml}$ filtrate, $2 \mathrm{ml} 0.2 \mathrm{M}$ sodium phosphate buffer $(\mathrm{pH} 7.2)$ and $0.5 \mathrm{ml} 0.02 \% \mathrm{DNPH}$. The mixture was incubated for $30 \mathrm{~min}$ at $37^{\circ} \mathrm{C}$. After incubation $5 \mathrm{ml} 0.8 \mathrm{~N} \mathrm{NaOH}$ was added and incubated for $10 \mathrm{~min}$ at room temperature. After incubation absorbance of brown colour was measured spectrophotometrically at $510 \mathrm{~nm}$. The pyruvate contents was estimated using a standard curve of sodium pyruvate and expressed as $\mathrm{mg} \mathrm{g}^{-1} \mathrm{FW}$ (Sadasivam and Manickam, 2008).

\subsubsection{Citric acid content}

Plant sample (both roots and shoots of rice cv. MTU-1010) of $1 \mathrm{~g}$ from each treatment was extracted in 5 $\mathrm{ml} 0.2 \mathrm{M}$ sodium phosphate buffer ( $\mathrm{pH} 7.4$ ), centrifuged at $10,000 \mathrm{rpm}$ for $15 \mathrm{~min}$ at $4^{\circ} \mathrm{C}$. The supernatant was deproteinized with $5 \%$ TCA and filtered. Reaction mixture containing $1 \mathrm{ml}$ filtrate, $1.3 \mathrm{ml}$ analytical grade pyridine, $5 \mathrm{ml}$ analytical grade acetic anhydride and incubated for $30 \mathrm{~min}$ at $32 \pm 2{ }^{\circ} \mathrm{C}$. After $30 \mathrm{~min}$ the absorbance of the sample was measured spectrophotometrically at $405 \mathrm{~nm}$. The citrate contents was estimated using a standard curve of sodium citrate and expressed as $\mathrm{mg} \mathrm{g}^{-1} \mathrm{FW}$ (Saffran and Denstedt, 1948).

\subsubsection{Succinic acid content}

Plant sample (both roots and shoots of rice cv. MTU-1010) of $1 \mathrm{~g}$ from each treatment was crushed in liquid $\mathrm{N}_{2}$ and extracted in $5 \mathrm{ml}$ buffer containing $0.4 \mathrm{M}$ mannitol, $1 \mathrm{mM}$ EDTA, $50 \mathrm{mM}$ Tris (pH 8.2). The extracts were centrifuged at $20,000 \mathrm{~g}$ for $20 \mathrm{~min}$ at $0^{\circ} \mathrm{C}$. The pellets containing mitochondrial fraction were dissolved in sodium phosphate buffer ( $\mathrm{pH} 7.6$ ). Reaction mixture was comprised of $0.5 \mathrm{ml}$ assay 
buffer ( $\mathrm{pH} 7.6), 0.1 \mathrm{ml}$ mitochondrial suspension and sodium succinate standard solution to turn out the final volume $1 \mathrm{ml}$. It was kept in ice for $15 \mathrm{~min}$ followed by re-incubation for $60 \mathrm{~min}$ at $37^{\circ} \mathrm{C}$. The developed red coloured formazan was extracted in $4 \mathrm{ml} \mathrm{CH}_{3} \mathrm{COOC}_{2} \mathrm{H}_{5}$. The absorbance of formazan was measured at $490 \mathrm{~nm}$. The succinate contents present in the samples were estimated by using a standard curve of sodium succinate and expressed as $\mathrm{mg} \mathrm{g}^{-1} \mathrm{FW}$ (Valle et al. 1978).

\subsubsection{Malic acid contents}

Plant sample (both roots and shoots of rice cv. MTU-1010) of $1 \mathrm{~g}$ from each treatment was extracted in 5 $\mathrm{ml} 0.2 \mathrm{M}$ sodium phosphate buffer ( $\mathrm{pH} 7.4)$ and centrifuged at $10,000 \mathrm{rpm}$ for $15 \mathrm{~min}$ at $4^{\circ} \mathrm{C}$. The supernatant was deproteinized with $5 \%$ TCA and filtered. Reaction mixture was comprised of $1 \mathrm{ml}$ filtrate, $2 \mathrm{ml} 1 \mathrm{~N} \mathrm{HCl}, 0.2 \mathrm{ml} 0.1 \% \mathrm{DNPH}$ and $1 \mathrm{ml} 10 \% \mathrm{CaCl}_{2}$. It was incubated for $30 \mathrm{~min}$ at room temperature followed by addition of $0.6 \mathrm{ml} 5 \mathrm{~N} \mathrm{NH}_{4} \mathrm{OH}$ and $12 \mathrm{ml}$ absolute alcohol to it and kept for $12 \mathrm{~h}$ at room temperature for precipitation. Then it was centrifuged at 5,000 rpm at room temperature for $15 \mathrm{~min}$. The pellet was dried and mixed with $4 \mathrm{ml} 0.08 \%$ orcinol sulphuric acid. After cooling, in the reaction mixture $10 \mathrm{ml}$ conc. $\mathrm{H}_{2} \mathrm{SO}_{4}$ was added. The fluorescence of the resulting product was estimated by using a Hitachi-650-40 spectrofluorometer. The malic acid contents was expressed as $\mathrm{mg} \mathrm{g}^{-1} \mathrm{FW}$ (Hummel, 1949).

\subsection{Assay of the activities of respiratory enzymes 2.3.1. Pyruvate dehydrogenase (PDH; EC 1.2.4.1) activity}

Plant sample (both roots and shoots of rice cv. MTU-1010) of $1 \mathrm{~g}$ from each treatment was homogenized in $5 \mathrm{ml} 50 \mathrm{mM}$ Tris-HCl buffer ( $\mathrm{pH}$ 7.8) containing $0.7 \mathrm{M}$ sucrose, $57 \mathrm{mM} \beta$-mercaptoethanol, $2 \mathrm{mM}$ EDTA and $0.5 \%(\mathrm{w} / \mathrm{v}) \mathrm{BSA}$. It was centrifuged at $10,000 \mathrm{rpm}$ for $20 \mathrm{~min}$ at $4{ }^{\circ} \mathrm{C}$ and supernatant was collected. Reaction mixture was comprised of $0.5 \mathrm{ml}$ supernatant, $0.5 \mathrm{ml} 50 \mathrm{mM}$ Tris- $\mathrm{HCl}(\mathrm{pH} 8)$ and $0.2 \mathrm{ml}$ each of $5 \mathrm{mM} \mathrm{MgCl}_{2}, 0.12 \mathrm{mM}$ Co-A, $2.6 \mathrm{mM}$ cysteine $\mathrm{HCl}$ and $1.5 \mathrm{mM}$ pyruvate. The initial absorbance was recorded at $340 \mathrm{~nm}$. Then $0.5 \mathrm{ml} 1.4 \mathrm{mM}$ nicotinamide adenine dinucleotide (NAD) was added to it and immediately measured the absorbance at $340 \mathrm{~nm}$. The increment in optical density (OD) value was observed indicating the production of NADH per min. The PDH activity was calculated by using a standard curve with known concentrations of NADH and expressed as $\mu$ mole NADH formed $\mathrm{mg}^{-1}$ protein $\min ^{-1}$ (Williams and Randall, 1979).

\subsubsection{Isocitrate dehydrogenase (ICDH; EC 1.1.1.41) activity}

Plant sample (both roots and shoots of rice cv. MTU-1010) of $1 \mathrm{~g}$ from each treatment was crushed in liquid $\mathrm{N}_{2}$ and homogenized in $5 \mathrm{ml} 50 \mathrm{mM}$ HEPES buffer ( $\mathrm{pH} \mathrm{7.5)} \mathrm{containing} 10 \mathrm{mM} \beta$-mercaptoethanol and $5 \%$ PVP. It was centrifuged at $14,500 \mathrm{~g}$ for $20 \mathrm{~min}$ at $4{ }^{\circ} \mathrm{C}$ and supernatant was collected. Reaction mixture was comprised of $0.4 \mathrm{ml} 40 \mathrm{mM}$ HEPES buffer ( $\mathrm{pH} 8.2), 0.2 \mathrm{ml} 2 \mathrm{mM}$ sodium isocitrate, $0.1 \mathrm{ml}$ $200 \mathrm{mM} \mathrm{MnSO}_{4}$ and $0.4 \mathrm{ml}$ supernatant. The initial absorbance was recorded at $340 \mathrm{~nm}$ against blank. Then $0.1 \mathrm{ml} 800 \mathrm{mM}$ NAD was added to it and measured the absorbance at $340 \mathrm{~nm}$ for $5 \mathrm{~min}$ in every 60 
s interval. The ICDH activity was calculated by using a standard curve with known concentrations of $\mathrm{NADH}$ and expressed as $\mu$ mole NADH formed $\mathrm{mg}^{-1}$ protein $\mathrm{min}^{-1}$ (Zhou et al. 2012).

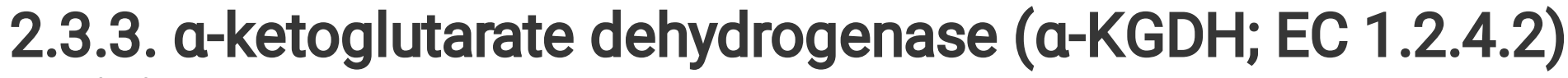 activity}

Plant sample (both roots and shoots of rice cv. MTU-1010) of $1 \mathrm{~g}$ from each treatment was crushed in liquid $\mathrm{N}_{2}$ and homogenized in $5 \mathrm{ml} 50 \mathrm{mM} \mathrm{MOPS-HCl}$ buffer (pH 7.5). It was centrifuged at 10,000 rpm for $20 \mathrm{~min}$ at $4^{\circ} \mathrm{C}$ and supernatant was collected. Reaction mixture was comprised of $0.6 \mathrm{ml} 75 \mathrm{mM}$ TES$\mathrm{KOH}$ (pH 7.5), $0.3 \mathrm{ml} 0.05 \%$ (w/v) Triton-X-100, $0.25 \mathrm{ml} 0.5$ mM MgCl $2,0.2 \mathrm{ml} 0.12 \mathrm{mM}$ lithium Co-A, 0.14 $\mathrm{ml} 0.2 \mathrm{mM}$ TPP, $0.25 \mathrm{ml} 2.5 \mathrm{mM}$ cysteine-HCl, $0.2 \mathrm{ml} 1 \mathrm{mM}$ AMP, $0.25 \mathrm{ml} 1 \mathrm{mM}$ sodium 2-oxoglutarate, 3 units lipoamide dehydrogenase and $0.5 \mathrm{ml}$ supernatant. The initial absorbance was recorded at $340 \mathrm{~nm}$ against blank. Then $0.3 \mathrm{ml} 2 \mathrm{mM} \mathrm{NAD}$ was added to it and measured the absorbance at $340 \mathrm{~nm}$ for 5 min in every $60 \mathrm{~s}$ interval. The a-KGDH activity was calculated by using a standard curve with known concentrations of NADH and expressed as $\mu$ mole NADH formed $\mathrm{mg}^{-1}$ protein $\mathrm{min}^{-1}$ (Millar et al. 1999).

\subsubsection{Succinate dehydrogenase (SDH; EC 1.3.5.1) activity}

Plant sample (both roots and shoots of rice cv. MTU-1010) of $1 \mathrm{~g}$ from each treatment was homogenized in $5 \mathrm{ml} 4 \mathrm{mM}$ Tris-HCl buffer ( $\mathrm{pH} 7.5$ ) containing $0.19 \mathrm{M}$ sucrose. It was centrifuged at 10,000 rpm for 15 min at $4{ }^{\circ} \mathrm{C}$ and supernatant was collected. Reaction mixture was composed of $0.1 \mathrm{ml}$ each of $0.19 \mathrm{M}$ sucrose, 0.1 M Tris- $\mathrm{HCl}$ ( $\mathrm{pH} 7.5), 10 \mathrm{mM} \mathrm{NaN}_{3}, 8 \mathrm{mM}$ INT, $0.2 \mathrm{ml} 0.5 \mathrm{M}$ sodium succinate, $0.2 \mathrm{ml}$ distilled $\mathrm{H}_{2} \mathrm{O}$ and $0.2 \mathrm{ml}$ supernatant and was kept in a water-bath at $30^{\circ} \mathrm{C}$ for $10 \mathrm{~min}$. After incubation, $0.5 \mathrm{ml}$ $95 \%$ alcohol was added to the reaction mixture and placed in an ice bath for another 15 min followed by centrifugation at 8,000 rpm for $10 \mathrm{~min}$ at room temperature. The absorbance of the supernatant was measured spectrophotometrically at $458 \mathrm{~nm}$. The enzyme activity was expressed as $\mu$ mol INT reduced $\mathrm{mg}^{-1}$ protein $\min ^{-1}$ (Green and Narahara, 1980).

\subsubsection{Fumarase (EC 4.2.1.2) activity}

Fumarase activity was assayed according to the method of Bergmeyer et al. (1974). Plant sample (both roots and shoots of rice cv. MTU-1010) of $1 \mathrm{~g}$ from each treatment was homogenized in $5 \mathrm{ml} 100 \mathrm{mM}$ potassium phosphate buffer $\left(\mathrm{pH} \mathrm{7.6)}\right.$ at $25^{\circ} \mathrm{C}$. Then it was centrifuged at $10,000 \mathrm{~g}$ for $20 \mathrm{~min}$ at $4^{\circ} \mathrm{C}$ and supernatant was collected. Reaction mixture was composed of $0.5 \mathrm{ml} 70 \mathrm{mM}$ phosphate buffer ( $\mathrm{pH} 7.4$ ), $0.5 \mathrm{ml}$ supernatant and $0.3 \mathrm{ml} 50 \mathrm{mM}$ malate. Malate transformation was recorded by the change in

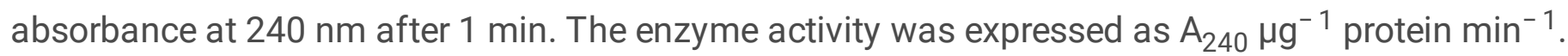

\subsubsection{Malate dehydrogenase (MDH; EC 1.1.1.37) activity}

Plant sample (both roots and shoots of rice cv. MTU-1010) of $1 \mathrm{~g}$ from each treatment was homogenized in $5 \mathrm{ml} 50 \mathrm{mM}$ Tris-HCl buffer ( $\mathrm{pH}$ 8) containing $50 \mathrm{mM} \mathrm{MgCl}_{2}, 5 \mathrm{mM} \beta$-mercaptoethanol and $1 \mathrm{mM}$ EDTA. It was centrifuged at 10,000 rpm for $20 \mathrm{~min}$ at $4^{\circ} \mathrm{C}$. Reaction mixture was composed of $0.5 \mathrm{ml} 5$ mM OAA, $0.5 \mathrm{ml} 10 \mathrm{mM} \mathrm{MgCl}_{2}, 1.5 \mathrm{ml} 0.1 \mathrm{M}$ Tris-HCl buffer (pH 7.8) and $0.2 \mathrm{ml}$ supernatant. The initial 
absorbance was recorded at $340 \mathrm{~nm}$. Then $0.5 \mathrm{ml} 0.4 \mathrm{mM} \mathrm{NADH}$ was added to it and measured the absorbance at $340 \mathrm{~nm}$ for $5 \mathrm{~min}$. The MDH activity was calculated by using a standard curve of NADH and expressed as $\mu$ mole NADH oxidized $\mathrm{mg}^{-1}$ protein $\min ^{-1}$ (Kumar et al. 2000).

\subsubsection{Citrate synthase (CS; EC 2.3.3.1) activity}

Plant sample (both roots and shoots of rice cv. MTU-1010) of $1 \mathrm{~g}$ from each treatment was homogenized in $5 \mathrm{ml}$ homogenization buffer comprising $0.1 \mathrm{mM}$ Tris-HCl buffer (pH 8), 0.1\% (w/v) Triton-X-100, 2\% PVP and $10 \mathrm{mM}$ iso-ascorbic acid. It was centrifuged at $15,000 \mathrm{rpm}$ for $5 \mathrm{~min}$ at $4^{\circ} \mathrm{C}$. Reaction mixture was composed of $0.3 \mathrm{ml} 1 \mathrm{mM}$ DTNB, $0.2 \mathrm{ml} 10 \mathrm{mM}$ acetyl Co-A and $0.5 \mathrm{ml}$ supernatant. The initial absorbance was recorded at $412 \mathrm{~nm}$ against blank. Then $0.2 \mathrm{ml} 10 \mathrm{mM}$ OAA was added to it and measured the absorbance at $412 \mathrm{~nm}$ for $5 \mathrm{~min}$. The CS activity was expressed as $\mu \mathrm{g}$ citric acid formed $\mathrm{mg}^{-1}$ protein $\mathrm{min}^{-1}$ (Srere et al. 1969).

\subsection{Estimation of GABA and assay of its regulatory enzymes}

\subsubsection{GABA ( $\gamma$-aminobutyric acid) contents}

GABA contents was estimated according to the method of Kitaoka and Nakano (1969). Plant sample (both roots and shoots of rice cv. MTU-1010) of $1 \mathrm{~g}$ from each treatment was homogenized in $80 \%$ ethanol and filtered. Ethanol was removed from the filtrate, dissolved in $\mathrm{H}_{2} \mathrm{O}$ and centrifuged at 10,000 rpm for $10 \mathrm{~min}$ at room temperature. The supernatant was collected. Reaction mixture was composed of $0.5 \mathrm{ml}$ supernatant, $0.2 \mathrm{ml} 0.2 \mathrm{M}$ borate buffer and $1 \mathrm{ml} 6 \%$ phenol, cooled and $0.4 \mathrm{ml} 10 \% \mathrm{NaOCl}$ was added. The mixture was shaken, boiled in water-bath for $10 \mathrm{~min}$ and left for cooling. Absorbance of the reaction mixture was measured at $630 \mathrm{~nm}$. GABA contents were quantified from the $O D$ values using the GABA standard curve and expressed as $\mathrm{mg} \mathrm{g}^{-1} \mathrm{FW}$.

\subsubsection{Glutamate dehydrogenase (GDH; EC 1.4.1.2) activity}

Plant sample (both roots and shoots of rice cv. MTU-1010) of $1 \mathrm{~g}$ from each treatment was crushed in liquid $\mathrm{N}_{2}$ and extracted in $5 \mathrm{ml}$ of homogenization buffer consisted of $0.1 \mathrm{M}$ Tris-HCl, $5 \mathrm{mM}$ EDTA, $10 \mathrm{mM}$ DTT, $1 \mathrm{mM}$ pyridoxal-5'-phosphate hydrate and 1\% PVP (pH 7.8). It was centrifuged at 10,000 g for 10 min at $4{ }^{\circ} \mathrm{C}$ and supernatant was collected. Reaction mixture was comprised of $0.5 \mathrm{ml}$ supernatant, $0.2 \mathrm{ml}$ $\left(\mathrm{NH}_{4}\right)_{2} \mathrm{SO}_{4}, 0.3 \mathrm{ml} 13 \mathrm{mM}$ a-ketoglutarate, $0.25 \mathrm{ml} 0.25 \mathrm{mM}$ NADPH, $0.5 \mathrm{ml} 100 \mathrm{mM}$ Tris-HCl buffer (pH 8) and $0.2 \mathrm{ml} \mathrm{CaCl}_{2}$. The absorbance was measured at $340 \mathrm{~nm}$ using spectrophotometer and GDH activity was expressed as $\mu$ mole NADH mg ${ }^{-1}$ protein $\min ^{-1}$ (Akihiro et al. 2008).

\subsubsection{Glutamate decarboxylase (GAD; EC 4.1.1.15) activity}

According to Bartyzel et al. (2003) GAD activity was assayed. Plant sample (both roots and shoots of rice cv. MTU-1010) of $1 \mathrm{~g}$ from each treatment was crushed in liquid $\mathrm{N}_{2}$ and extracted in $5 \mathrm{ml}$ homogenization buffer consisted of $0.1 \mathrm{M}$ Tris-HCl, 5 mM EDTA, 10 mM DTT, 1 mM pyridoxal-5'-phosphate hydrate and 
$1 \%$ PVP (pH 7.8). It was centrifuged at $10,000 \mathrm{~g}$ for $10 \mathrm{~min}$ at $4^{\circ} \mathrm{C}$ and supernatant was collected. Reaction mixture was comprised of $0.2 \mathrm{ml}$ supernatant, $0.15 \mathrm{ml} 20 \mu \mathrm{M}$ pyridoxal phosphate and $0.4 \mathrm{ml}$ potassium phosphate buffer $\left(\mathrm{pH}\right.$ 5.8). The reaction sets were kept for $10 \mathrm{~min}$ at $30^{\circ} \mathrm{C}$, then $0.3 \mathrm{ml} 3 \mathrm{mM}$ L-glutamate was added and incubated for $1 \mathrm{~h}$. The reaction was terminated by adding $0.5 \mathrm{M} \mathrm{HCl}$ followed by centrifugation. The supernatant was derivatized using $0.35 \%(\mathrm{w} / \mathrm{v})$ ninhydrin solution. The absorbance was measured at $340 \mathrm{~nm}$ using spectrophotometer and the enzyme activity was expressed as $\mathrm{mg}$ GABA formed $\mathrm{mg}^{-1}$ protein $\mathrm{min}^{-1}$.

\subsubsection{GABA transaminase (GABA-T; EC 2.6.1.19) activity}

Plant sample (both roots and shoots of rice cv. MTU-1010) of $1 \mathrm{~g}$ from each treatment was homogenized in $5 \mathrm{ml} 50 \mathrm{mM}$ Tris-HCl buffer ( $\mathrm{pH} 8.5$ ) containing $0.32 \mathrm{M}$ sucrose, $0.67 \%$ Triton- $\mathrm{X}-100,4.5 \mathrm{mM} \beta$ mercaptoethanol. It was centrifuged at $10,000 \mathrm{rpm}$ for $15 \mathrm{~min}$ at $4^{\circ} \mathrm{C}$ and supernatant was collected. Reaction mixture was comprised of $0.3 \mathrm{ml}$ supernatant, $0.25 \mathrm{ml} 50 \mathrm{mM}$ Tris-HCl buffer (pH 8.5), $0.15 \mathrm{ml} 2$ $\mathrm{mM}$ 2-oxoglutaric acid, $0.1 \mathrm{ml} 20 \mathrm{mM} \beta$-mercaptoethanol and $0.16 \mathrm{ml} 1.1 \mathrm{mM} \mathrm{NAD}$ followed by incubation for $30 \mathrm{~min}$ at $22^{\circ} \mathrm{C}$. Now, $0.2 \mathrm{ml} 3 \mathrm{mM} \mathrm{GABA}$ was added to the reaction mixture and incubated in ice for $10 \mathrm{~min}$. The NADH formation was measured at $340 \mathrm{~nm}$ using spectrophotometer and the enzyme activity was expressed as $\mu$ mole NADH formed $\mathrm{mg}^{-1}$ protein $\mathrm{min}^{-1}$ (Yazdanparast and Qujeq, 1994).

\subsection{Estimation of polyamines contents by TLC \& HPLC 2.5.1. Preparation of perchloric acid extract}

Polyamine content was analyzed from the test materials (both roots and shoots of rice cv. MTU-1010) using TLC and HPLC methods according to Flores \& Galstone (1982) and Redmond \& Tseng (1979), respectively. From each set, $1 \mathrm{~g}$ tissue was extracted in $5 \mathrm{ml} 10 \%$ ice-cold $\mathrm{HClO}_{4}$. The extracts were centrifuged at $48,000 \mathrm{~g}$ for $20 \mathrm{~min}$ at $0^{\circ} \mathrm{C}$. The supernatant containing 'free' polyamine fraction was stored at $-20^{\circ} \mathrm{C}$.

\subsubsection{Dansylation and TLC Analysis of polyamines}

The reaction mixture was prepared with $0.2 \mathrm{ml}$ supernatant, $0.4 \mathrm{ml}$ dansyl chloride and $0.2 \mathrm{ml}$ saturated $\mathrm{Na}_{2} \mathrm{CO}_{3}$. After vortexing, the mixture was incubated in dark for overnight at $24^{\circ} \pm 2^{\circ} \mathrm{C}$. Dansylated amines were extracted in $0.5 \mathrm{ml}$ benzene and upper organic phase was collected. Standards were processed in the same manner and $0.1 \mathrm{ml}(1 \mathrm{mg} / \mathrm{ml})$ was dansylated for each cases. About $80 \mu \mathrm{l}$ of dansylated extract for each parameter was loaded on the pre-adsorbent zone of TLC silica gel $60 \mathrm{~F}_{254}$, bought from Merck, Germany and the chromatogram was developed with the solvent system, cyclohexane:ethylacetate (5:4, $\mathrm{v} / \mathrm{v}$ ). Identification of the unknown spots was done by comparison of RFs. The dansyl polyamine bands were scraped from the TLC plate, eluted in $4 \mathrm{ml}$ ethylacetate by vortex followed by centrifugation at 4000 rpm for 5 min at $4^{\circ} \mathrm{C}$ and quantified by using a Hitachi-650-40 spectrofluorometer with excitation at 360 $\mathrm{nm}$ and emission at $506 \mathrm{~nm}$. 


\subsubsection{Benzoylation and HPLC analysis of polyamines}

The reaction mixture was prepared with $1 \mathrm{ml} 2 \mathrm{~N} \mathrm{NaOH}, 0.5 \mathrm{ml} \mathrm{HClO}_{4}$ extract and $10 \mu \mathrm{l}$ benzoyl chloride, vortexed followed by incubation for $20 \mathrm{~min}$ at $22^{\circ} \mathrm{C} \pm 2^{\circ} \mathrm{C}$. Subsequently $2 \mathrm{ml}$ saturated $\mathrm{NaCl}$ was added and the benzoyl-polyamines were extracted in $2 \mathrm{ml}$ diethyl ether, centrifuged at $1,500 \mathrm{~g}$ for $5 \mathrm{~min}$ at $4^{\circ} \mathrm{C}$. Then, $1 \mathrm{ml}$ ether phase was collected, evaporated and re-dissolved in $100 \mu \mathrm{l}$ acetonitrile. Finally, $10 \mu \mathrm{l}$ of each derivatized sample was injected for HPLC analysis. The derivatives were isolated by using Shimadzu Nova Pak C18 analytical column. The solvent system consisted of acetonitrile:water (52\%, $\mathrm{v} / \mathrm{v}$ ). Unknown peaks of polyamines were detected at $254 \mathrm{~nm}$ and identified with respect to the standard peaks. Peak area percentage was obtained from the peak table generated from Labsolutions software in Shimadzu uflc, model - prominence.

\subsection{Protein estimation}

The protein contents of enzyme extracts were estimated according to Lowry et al. (1951). The blue colour intensity of the samples were recorded at $660 \mathrm{~nm}$. The amount of protein present in the samples were calculated from the standard curve prepared using bovine serum albumin (BSA) as standard.

\subsection{Statistical analysis}

For each treatment and control, three independent experiments were performed i.e. two replicates with three repeats in each experiment $(n=6)$. The measurements obtained on all the experimental parameters were summarized as (means \pm SE) over these replicated experiments. We had used SPSS software (PASW Statistics 18: Version 18.0.0.282) to analyze these results statistically. Tukey's HSD (Honest Significant Difference) pairwise-comparison of means was used to compare the effects of different treatment levels, along with control, separately for Si and Se supplementations in As(V) treated rice seedlings.

For co-treatments of both $\mathrm{Si}$ and Se along with $\mathrm{As}(\mathrm{V})$, separate two-way ANOVA was performed for the respective $4 \times 2$ block design with four levels of As [Control, $25 \mu \mathrm{M}, 50 \mu \mathrm{M}$ and $75 \mu \mathrm{M} \mathrm{As}(\mathrm{V})$ ] and two levels of Si or Se (applied and not applied), respectively. A full factorial model, including interaction effect, in these two-way ANOVA and the significance of the main effects of Si or Se were used to compare the ameliorative effects of these supplementations.

\section{Results}

\subsection{Influence of $A s(V)$ with or without Si and Se on Krebs cycle intermediates}

\subsubsection{Pyruvic acid content}


Pyruvic acid contents was increased in 3 weeks old rice seedlings under $A s(V)$ stress. In root, the said contents was increased by about 35, 44 and 55\% while in shoot it was increased by about 25,42 and $52 \%$ under 25, 50 and $75 \mu \mathrm{M} \mathrm{As}(\mathrm{V})$ treatments respectively, over control. During co-application of 25, 50 and $75 \mu \mathrm{M} \mathrm{As}(\mathrm{V})$ and Si, the said contents were increased further by about $69,83,90 \%$ in root and $35,69,77 \%$ in shoot respectively, over control [Table 1]. Under co-application of Se along with said concentrations of $\mathrm{As}(\mathrm{V})$, the pyruvic acid contents were increased more than $\mathrm{As}(\mathrm{V})$ treatments alone but less than $\mathrm{Si}+\mathrm{As}(\mathrm{V})$ treatments, that were about $46,51,67 \%$ in root and $27,47,59 \%$ in shoot respectively, over control

[Table 1].

\subsubsection{Citric acid content}

Citric acid contents was significantly increased in the test seedlings under $\mathrm{As}(\mathrm{V})$ stress. In root, the citrate contents was increased by about 30, 44 and $47 \%$ while in shoot it was increased by about 15,37 and $49 \%$ under 25, 50 and $75 \mu \mathrm{M} \mathrm{As}(\mathrm{V})$ treatments respectively, over control. During co-application of 25, 50 and $75 \mu \mathrm{M} \mathrm{As}(\mathrm{V})$ and Si, the said contents were increased further by about 58, 85, 94\% in root and 49, 61, 73\% in shoot respectively, over control [Table 1]. Under co-application of Se along with said concentrations of $\mathrm{As}(\mathrm{V})$, the citric acid contents were increased more than $\mathrm{As}(\mathrm{V})$ treatments alone but less than $\mathrm{Si}+\mathrm{As}(\mathrm{V})$ treatments, that were about $36,47,66 \%$ in root and $31,43,52 \%$ in shoot respectively, over control [Table 1].

\subsubsection{Succinic acid content}

Succinic acid contents was significantly increased in both root and shoot of 3 weeks old rice seedlings under As(V) stress. In root, said contents was increased by about 54, 67 and 76\% while in shoot it was increased by about 52, 61 and $66 \%$ under 25, 50 and $75 \mu \mathrm{M} \mathrm{As}(\mathrm{V})$ treatments respectively, over control. During co-application of 25, 50 and $75 \mu \mathrm{M} \mathrm{As}(\mathrm{V})$ and $\mathrm{Si}$, the said contents were increased more by about $71,90,96 \%$ in root and $67,77,81 \%$ in shoot respectively, over control [Table 1]. Under co-application of Se along with said concentrations of $\mathrm{As}(\mathrm{V})$, the succinate contents were increased more than $\mathrm{As}(\mathrm{V})$ treatments alone but less than $\mathrm{Si}+\mathrm{As}(\mathrm{V})$ treatments, that were about 60, 71 and $81 \%$ in root and 56, 66 and $71 \%$ in shoot respectively, over control [Table 1].

\subsubsection{Malic acid content}

Malic acid contents was significantly increased in the test seedlings under As(V) stress. In root, the malate contents was increased by about 33, 43 and $50 \%$ while in shoot it was increased by about 22,31 and $43 \%$ under 25, 50 and $75 \mu \mathrm{M} \mathrm{As}(\mathrm{V})$ treatments respectively, over control. Joint application of Si and said concentrations of $\mathrm{As}(\mathrm{V})$, said contents was increased more by about 58, 71, 94\% in root and 51, 62, $74 \%$ in shoot respectively, over control [Table 1]. Under co-application of Se along with said concentrations of $\mathrm{As}(\mathrm{V})$, the malate contents were increased more than $\mathrm{As}(\mathrm{V})$ treatments alone but less than $\mathrm{Si}+\mathrm{As}(\mathrm{V})$ treatments, that were about 42, 46 and $61 \%$ in root and 34, 40 and 47\% in shoot respectively, over control [Table 1]. 


\subsection{Influence of $\mathrm{As}(\mathrm{V})$ with or without $\mathrm{Si}$ and $\mathrm{Se}$ on the activities of respiratory enzymes}

\subsubsection{Pyruvate dehydrogenase (PDH; EC 1.2.4.1) activity}

In the test seedlings, PDH activity was decreased under $\mathrm{As}(\mathrm{V})$ stress. The enzyme activity was decreased in root by about 48, 58 and $83 \%$ while in shoot by about 38, 51 and 78\% under 25, 50 and $75 \mu \mathrm{M}$ As(V) treatments respectively, over control. When Si was applied along with same concentrations of $A s(V)$, relatively less decrease in PDH activity was recorded compared to $\mathrm{As}(\mathrm{V})$ treatment alone that were about 12, 21 and $26 \%$ in root and 5, 12 and 17\% in shoot respectively, over control [Fig. 1(a)]. In rice seedlings, Se application did not show any notable decrease than Si application in As(V) treated media. During Se+ $\mathrm{As}(\mathrm{V})$ application, the said activity was decreased by about 27,39 and $43 \%$ in root and 15,27 and $44 \%$ in shoot respectively, over control [Fig. 1(b)].

\subsubsection{Isocitrate dehydrogenase (ICDH; EC 1.1.1.41) activity}

In rice seedlings, ICDH activity was decreased under $\mathrm{As}(\mathrm{V})$ application. In root, the enzyme activity was decreased by about 64, 74 and $89 \%$ while in shoot it was decreased by about 51,66 and $71 \%$ under 25 , 50 and $75 \mu \mathrm{M} \mathrm{As}(\mathrm{V})$ treatments respectively, over control. When Si was applied along with As(V) there was relatively less decrease in ICDH activity that were about $15,24,30 \%$ in root and $13,19,21 \%$ in shoot under $\mathrm{Si}+25$, Si + 50 and $\mathrm{Si}+75 \mu \mathrm{M} \mathrm{As}(\mathrm{V})$ treatments respectively, over control [Fig. 2(a)]. During Se + $\mathrm{As}(\mathrm{V})$ application in the test seedlings, the enzyme activity was decreased by about 25,48 and $60 \%$ in root and 23, 30 and $49 \%$ in shoot respectively, over control [Fig. 2(b)].

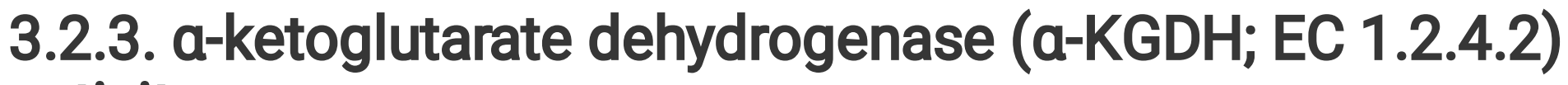 activity}

In the test seedlings, the a-KGDH activity was decreased under $\mathrm{As}(\mathrm{V})$ application. The enzyme activity was decreased in root by about 74, 86 and $92 \%$ while in shoot by about 64,75 and $84 \%$ under 25,50 and $75 \mu \mathrm{M}$ As(V) treatments respectively, over control. When Si was supplemented along with 25,50 and 75 $\mu \mathrm{M} \mathrm{As}(\mathrm{V})$ there was relatively less decrease in a-KGDH activity by about $23,28,38 \%$ in root and 20,25 , $32 \%$ in shoot respectively, over control [Fig. 3(a)]. During Se + said concentrations of As(V) application in the test seedlings, the enzyme activity was reduced further than $\mathrm{Si}+\mathrm{As}(\mathrm{V})$ application but reduced less, than $\mathrm{As}(\mathrm{V})$ treatments alone that were by about $47,57,61 \%$ in root and $46,52,55 \%$ in shoot respectively, over control [Fig. 3(b)].

\subsubsection{Succinate dehydrogenase (SDH; EC 1.3.5.1) activity}

SDH activity was decreased in the test seedlings under $\mathrm{As}(\mathrm{V})$ application. In root, the enzyme activity was decreased by about 69, 72 and $77 \%$ while in shoot it was decreased by about 54,60 and $65 \%$ under 25 , 50 and $75 \mu \mathrm{M} \mathrm{As}(\mathrm{V})$ treatments respectively, over control. When Si was supplemented along with 25,50 and $75 \mu \mathrm{M} \mathrm{As}(\mathrm{V})$ there was relatively less decrease in SDH activity by about 18, 22, 32\% in root and 10, $18,21 \%$ in shoot respectively, over control [Fig. 4(a)]. Se supplementation in As(V) treated test seedlings 
reduced the said activity more than $\mathrm{Si}+\mathrm{As}(\mathrm{V})$ treated test seedlings. During Se application along with $\mathrm{As}(\mathrm{V})$, the rate of reductions in enzyme activity were $37,56,62 \%$ in root and $33,49,56 \%$ in shoot respectively, over control [Fig. 4(b)].

\subsubsection{Fumarase (EC 4.2.1.2) activity}

Fumarase activity in the test seedlings increased under $\mathrm{As}(\mathrm{V})$ treatments. In root, the enzyme activity was increased by about 70, 77 and $88 \%$ while in shoot it was increased by about 66, 69 and $72 \%$ under 25,50 and $75 \mu \mathrm{M} \mathrm{As}(\mathrm{V})$ treatments respectively, over control. When Si was supplemented along with 25, 50 and $75 \mu \mathrm{M}$ As(V) there was relatively less increase in enzyme activity that was by about $25,33,36 \%$ in root and 10, 21, 26\% in shoot respectively, over control [Fig. 5(a)]. Se supplementation in As(V) treated test seedlings enhanced the said activity more than Si supplementation in $\mathrm{As}(\mathrm{V})$ treated medium. During joint application of $\mathrm{As}(\mathrm{V})$ and $\mathrm{Se}$, the rate of increments in enzyme activity were $35,46,58 \%$ in root and 22,40 , 41\% in shoot respectively, over control [Fig. 5(b)].

\subsubsection{Malate dehydrogenase (MDH; EC 1.1.1.37) activity}

The $\mathrm{MDH}$ activity was decreased under $\mathrm{As}(\mathrm{V})$ stress in the test seedlings. In root, the enzyme activity was decreased by about 79, 84 and $92 \%$ while in shoot it was decreased by about 61, 72 and $88 \%$ under 25 , 50 and $75 \mu \mathrm{M} \mathrm{As}(\mathrm{V})$ treatments respectively, over control. When Si was applied along with 25, 50 and 75 $\mu \mathrm{M} \mathrm{As}(\mathrm{V})$ there was relatively less decrease in $\mathrm{MDH}$ activity that was by about 20,27 and $36 \%$ in root and 19, 24 and 29\% in shoot respectively, over control [Fig. 6(a)]. During joint application of As(V) and Se, the rate of reductions were narrowed down to about $47,57,64 \%$ in root and $31,48,65 \%$ in shoot respectively, over control [Fig. 6(b)].

\subsubsection{Citrate synthase (CS; EC 2.3.3.1) activity}

The CS activity was decreased under As(V) stress in 3 weeks old rice seedlings. In root, the enzyme activity was decreased by about 76, 86 and 91\% while in shoot it was decreased by about 62, 69 and $76 \%$ under 25, 50 and $75 \mu \mathrm{M} \mathrm{As}(\mathrm{V})$ treatments respectively, over control. When Si was applied along with 25, 50 and $75 \mu \mathrm{M} \mathrm{As}(\mathrm{V})$ there was relatively less decrease in CS activity by about 22, 30 and $34 \%$ in root and 10, 23 and $27 \%$ in shoot respectively, over control [Fig. 7(a)]. During joint application with As(V) and Se, the rate of reductions were more than $\mathrm{Si}+\mathrm{As}(\mathrm{V})$ but less than $\mathrm{As}(\mathrm{V})$ treatments only that were by about $34,48,51 \%$ in root and $26,29,37 \%$ in shoot respectively, over control [Fig. 7 (b)].

3.3. Influence of arsenate with or without silicate and selenate on GABA accumulation and activities of its regulatory enzymes

\subsubsection{Y-aminobutyric acid (GABA) content}

In rice seedlings, GABA contents increased in $\mathrm{As}(\mathrm{V})$ treatments. The enhancement in GABA contents were about $54,72,97 \%$ in root and in shoot by about 31, 49, 75\% under 25, 50 and $75 \mu \mathrm{M} \mathrm{As}(\mathrm{V})$ treatments respectively, over control. When Si was applied along with said concentrations of $\mathrm{As}(\mathrm{V})$ there was relatively less increase in the said contents that were about $18,28,30 \%$ in root and $6,14,21 \%$ in shoot 
respectively, over control [Fig. 8(a)]. The rate of enhancement was more during Se application along with 25,50 and $75 \mu \mathrm{M} \mathrm{As}(\mathrm{V})$ than the jointly treated test seedlings with $\mathrm{As}(\mathrm{V})$ and Si. During joint application with $\mathrm{As}(\mathrm{V})$ and Se, the rate of increments in GABA contents were by about $31,43,51 \%$ in root and 18,29 , $43 \%$ in shoot respectively, over control [Fig. 8(b)].

\subsubsection{Glutamate dehydrogenase (GDH; EC 1.4.1.2) activity}

In the test seedlings, GDH activity was increased more under As(V) stress. In root, the enzyme activity was increased by about 43,68 and $77 \%$ while in shoot it was increased by about 33,44 and $60 \%$ under 25,50 and $75 \mu \mathrm{M}$ As(V) treatments respectively, over control. When Si was applied along with 25, 50 and $75 \mu \mathrm{M}$ As $(\mathrm{V})$, there was relatively less increase in GDH activity by about 18,24 and $32 \%$ in root and 10,14 and $24 \%$ in shoot respectively, over control [Fig. 9(a)]. During Se+ said concentrations of As(V) application in the test seedlings, the rate of increments were by about $26,37,48 \%$ in root and $18,32,40 \%$ in shoot respectively, over control [Fig. 9(b)].

\subsubsection{Glutamate decarboxylase (GAD; EC 4.1.1.15) activity}

In rice seedlings, GAD activity was increased more under $A s(V)$ stress. In root, the enzyme activity was increased by about 51, 64 and $90 \%$ while in shoot it was increased by about 39, 47 and $59 \%$ under 25, 50 and $75 \mu \mathrm{M} \mathrm{As}(\mathrm{V})$ treatments respectively, over control. When Si was applied along with $\mathrm{As}(\mathrm{V})$, there was relatively less increase in GAD activity than $A s(V)$ treatment alone that were about $24,26,29 \%$ in root and $11,17,19 \%$ in shoot under $\mathrm{Si}+25, \mathrm{Si}+50$ and $\mathrm{Si}+75 \mu \mathrm{M} \mathrm{As}(\mathrm{V})$ treatments respectively, over control [Fig. 10(a)]. The rate of enhancement was more during application of Se along with As(V) in the test seedlings than joint application of $\mathrm{As}(\mathrm{V})$ and $\mathrm{Si}$. In $\mathrm{As}(\mathrm{V})+$ Se treated seedlings, the increments in the said activity were by about $47,48,53 \%$ in root and $26,32,42 \%$ in shoot respectively, over control [Fig. 10(b)].

\subsubsection{GABA transaminase (GABA-T; EC 2.6.1.19) activity}

In rice seedlings, GABA-T activity was increased more under $\mathrm{As}(\mathrm{V})$ stress. In root, the enzyme activity was increased by about 66,87 and $90 \%$ while in shoot it was increased by about 41,63 and $73 \%$ under 25,50 and $75 \mu \mathrm{M} \mathrm{As}(\mathrm{V})$ treatments respectively, over control. When Si was applied along with said concentrations of $\mathrm{As}(\mathrm{V})$ there was relatively less increment in GABA-T activity that were about 20, 26 and $30 \%$ in root and 11,13 and $23 \%$ in shoot respectively, over control [Fig. 11(a)]. During joint application of As $(V)$ with Se the rate of increments in the enzyme activity were about $42,53,68 \%$ in root and $26,30,45 \%$ in shoot respectively, over control [Fig. 11(b)].

\subsection{Influence of arsenate with or without silicate and selenate on polyamines content}

\section{Estimation of polyamines content by using thin layer chromatography}

The polyamines viz. putrescine (Put), spermidine (Spd), and spermine (Spm) contents were detected from $\mathrm{As}(\mathrm{V}), \mathrm{As}(\mathrm{V})+\mathrm{Si}$ and $\mathrm{As}(\mathrm{V})+$ Se treated rice seedlings. In both root and shoot obtained from $\mathrm{As}(\mathrm{V})$ treated seedlings, the levels of Put was increased while Spd and Spm were decreased (Fig. 12-14). 
The Put contents was increased in root by about $30,37,45 \%$ and in shoot by about $24,28,36 \%$ under 25 , 50 and $75 \mu \mathrm{M}$ As $(\mathrm{V})$ treatments respectively, over control. During co-application of stated concentrations of $\mathrm{As}(\mathrm{V})$ with $\mathrm{Si}$, the Put contents had been detected more than $\mathrm{As}(\mathrm{V})$ treatment alone. The rate of increments were by about $52,88,98 \%$ in root and 38,59 and $89 \%$ in shoot respectively, over control [Fig. 12(a)]. Se application along with As(V) could not cause more increment in Put contents than $\mathrm{Si}+$ As(V) treatments and increased by about $26,39,50 \%$ in root and $28,44,66 \%$ in shoot respectively, over control [Fig. 12(b)].

The Spd contents was decreased by about $45,57,66 \%$ in root and $44,47,54 \%$ in shoot under 25,50 and $75 \mu \mathrm{M}$ As(V) treatments respectively, over control. During co-application of stated concentrations of $\mathrm{As}(\mathrm{V})$ with $\mathrm{Si}$, the level of Spd was also decreased but less than $\mathrm{As}(\mathrm{V})$ treatments alone. The reduction levels were about $7,11,16 \%$ in root and 5,8 and 10\% in shoot respectively, over control [Fig. 13(a)]. During application of $\mathrm{As}(\mathrm{V})$ with $\mathrm{Se}$, the said contents was decreased more than $\mathrm{Si}+\mathrm{As}(\mathrm{V})$ but less than only As $(V)$ treated test seedlings that were by about $12,32,39 \%$ in root and $29,31,33 \%$ in shoot respectively, over control [Fig. 13(b)].

The Spm contents was decreased by about $41,48,60 \%$ in root and $32,43,53 \%$ in shoot under 25,50 and $75 \mu \mathrm{M}$ As(V) treatments respectively, over control. During As(V) + Si application, the Spm level was decreased less than $A s(V)$ treatment alone. The reduction levels were about 15, 23, 26\% in root and 17, 21 and $28 \%$ in shoot under $\mathrm{Si}+25, \mathrm{Si}+50$ and $\mathrm{Si}+75 \mu \mathrm{M}$ As(V) treatments respectively, over control [Fig. 14(a)]. During joint application of $\mathrm{As}(\mathrm{V})$ with Se, the said contents were decreased more than $\mathrm{Si}+$ $\mathrm{As}(\mathrm{V})$ treatments but less than only $\mathrm{As}(\mathrm{V})$ treated test seedlings that were about $29,34,40 \%$ in root and 26, 34, 41\% in shoot respectively, over control [Fig. 14(b)].

\subsection{Overall comparative effects of Si and Se}

The main treatment effects, in terms of mitigating As induced toxicity on each of the physiological parameters considered in our study, were tested through the tests of between-subjects effects by performing separate two-way ANOVA for both Si and Se supplementation. The p values obtained from the above significance testing are presented in Table 2 for all the experimental factors in root and shoot. It can be seen that the ameliorative effects of $\mathrm{Si}$ is stronger than that of $\mathrm{Se}$ in all the cases ( $p$ values are lower for $\mathrm{Si}$ ).

\section{Discussion}

\subsection{Influence on Krebs cycle intermediates}

Organic acids produced in TCA cycle are important to carry out different biochemical pathways in cellular metabolism, acting as metabolically active solutes for osmotic adjustment leads to adaptation under different environmental stresses in plants (Xu et al. 2013, Nunes-Nesi et al. 2013). Lu et al. (2013) reported that metal-organic acid conjugates is associated with root-to-shoot transportation of metals in plants. Organic acids perform a pivotal role to develop some techniques in plants to overcome heavy metal toxicity, nutrient deficiency, and plant-microbe interactions in the soil rhizosphere (Oburger et al. 
2009). Citric acid implicated the solubilization of phosphate and increase its uptake by plants (Palomo et al. 2006). Song et al. (2011) reported that the levels of organic acids viz., acetic acid, citric acid, lactic acid, malic acid, succinic and maleic acid were high in roots of $\mathrm{cv}$. Baidan 31 in response to osmotic stress. In the study, $A s(V)$ treatment increased production of pyruvate, citrate, succinate and malate in the test seedlings. The citrate and malate anions secretes by the roots can form complexes with toxic metals in the rhizosphere that prevents binding of metals to cellular components resulting their detoxification (Yang et al. 2013). The organic solutes also shield cellular structures and biomolecules from ROS induced toxic consequences. Hui (2012) demonstrated that accumulation of organic acids under stress is an approach to stabilize $\mathrm{pH}$, ionic balance by buffering cation excess which is linked to deficiency of inorganic ions under stress that cause a deficit of negative charge. In the study, Si and Se supplementation in As(V) treated seedlings induced further in organic acids accumulation and effect was more pronounced during Si supplementation. This may be due to increased efflux of organic acids in the rhizosphere to chelate $\mathrm{As}(\mathrm{V})$ and restrict its entry to the plant.

\subsection{Influence on the activities of respiratory enzymes}

Plant mitochondria is directed by the respiratory cycle and associated electron transport chain. The respiratory cycle is also accountable for intracellular ROS generation resulting damage of metabolic pathways in the cell organelles (He et al. 2015). Decrease in dehydrogenase activity due to stress reduce the plant growth (Bouthour et al. 2012). PDH complex is associated with the TCA cycle in controlling carbon entry in the form of acetyl CoA (Nunes-Nesi et al. 2013). Arsenite binds to the lipoic acid moiety of transacetylase and inhibits the activity of PDH complex that hamper the TCA cycle, resulting cellular damage (Shen et al. 2013). The activity of citrate synthase (CS) is regulated by the cellular NADH/NAD ${ }^{+}$, ATP/ADP ratios and succinyl CoA levels (Cavalcanti et al. 2014). Isocitrate dehydrogenase (ICDH) regulates nitrogen assimilation and also tolerance to stress in Arabidopsis (Cavalcanti et al. 2014). A reduction in ICDH activity was observed in pea seedlings treated with $\mathrm{As}(\mathrm{V})$ that correspond to citrate accumulation indicating inhibition of TCA cycle (Bansal et al. 2002). ICDH is also known to maintain the redox potential in plant mitochondria (Hodges 2002). Therefore, under stressed environment reduced activity of this enzyme probably imbalance redox status in mitochondria. Shao et al. (2011) demonstrated that the activity of ICDH activity was decreased due to reduction in ICDH isozymes under $\mathrm{As}, \mathrm{Pb}, \mathrm{Cd}$ stresses in wheat seedlings. The activity of a-KGDH along with above three enzymes were reduced under heavy metal stress in germinating pea seeds (Bansal et al. 2002). Decrease in a-KGDH activity causes depletion in mitochondrial NADH pool that generates ROS and leads to oxidative stress (Shen et al. 2013, Araújo et al. 2014). Nunes-Nesi et al. (2011) stated that SDH controls the metabolic activities of plant mitochondria during respiratory cycle. Generation of ROS under $\mathrm{As}(\mathrm{V})$ stress inactivated the antioxidant enzymes, resulting $\mathrm{H}_{2} \mathrm{O}_{2}$ accumulation in the test cultivar. $\mathrm{H}_{2} \mathrm{O}_{2}$ inturn oxidized the thiol group of SDH and decreased its activity that resulted succinate accumulation. Increase in fumarase activity under $\mathrm{As}(\mathrm{V})$ stress caused malate accumulation. Increase in fumarase activity under cadmium stress has been reported in tomato (Lopez-Millan et al. 2009) and in mungbean under salt stress (Saha et al. 2012). Decrease in $M D H$ activity under $A s(V)$ stress could be correlated with malate accumulation in 
the test seedlings. Under Fe stress the decreased activity of MDH was reported in rice by Wang et al. (2013).

In the study, we observed significant decrease in the activities of studied respiratory enzymes viz., PDH, $\mathrm{ICDH}, \mathrm{a}-\mathrm{KGDH}, \mathrm{SDH}, \mathrm{MDH}, \mathrm{CS}$ and increase in fumarase activity in rice seedlings under $\mathrm{As}(\mathrm{V})$ stress. Coapplication of $\mathrm{Si}$ with $\mathrm{As}(\mathrm{V})$ and $\mathrm{Se}$ with $\mathrm{As}(\mathrm{V})$ increased the activities of tested enzymes because both $\mathrm{Si}$ and Se reduced $\mathrm{As}(\mathrm{V})$ uptake, resulted decrease in ROS formation and oxidative overload in the test cultivar. These results clearly validate the beneficial role of $\mathrm{Si}$ and Se to mitigate $\mathrm{As}(\mathrm{V})$ induced toxicity on respiratory activities and restored growth in the test seedlings.

\subsection{Influence on GABA accumulation and activities of its regulatory enzymes}

The metabolism of $y$-aminobutyric acid (GABA) is controlled by the activities of respiratory cycle enzymes via the production of succinic acid (Renault et al. 2010). GABA is supposed to sustain the cytosolic pH associated with the accumulation of organic acids during fruit development (Rolin et al. 2000). Recent studies of combined plant physiology and genetics exhibited the beneficial role of GABA shunt in maintenance of growth and metabolism with respect to various abiotic stresses (Michaeli et al. 2011, Renault et al. 2013, Nayyar et al. 2014, Rai et al. 2019). In cytosol, GABA is produced with the activities of two enzymes glutamate dehydrogenase (GDH) and glutamate decarboxylase (GAD) by using 2oxoglutarate and glutamate respectively as substrates (Fait et al. 2008). Additionally, GABA biosynthesis is associated with polyamine degradation especially from spermidine (Shelp et al. 2012a). Previous studies have documented the involvement of GABA shunt in several physiological responses viz., sustainability of cytosolic $\mathrm{pH}$, protection against oxidative stress, maintenance of $\mathrm{C} / \mathrm{N}$ pool and energy production (Rolin et al. 2000, Bouché and Fromm, 2004, Fait et al., 2008). GABA contents was found to be increased in Glycine max (Xing et al. 2007), tobacco (Allan et al. 2008), in Sesame indicum (Bor et al. 2009), Arabidopsis thaliana (Renault et al. 2010) and Nicotiana tabacum (Zhang et al. 2011, Akc, ay et al. 2012), in Solanum lycopersicum L. (Mae et al. 2013) in Brassica juncea (Mahmud et al. 2017) and in maize (Seifikalhor et al. 2020) under various abiotic stresses. Molina-Rueda et al. (2010) stated that in plants, glutamate decarboxylase (GAD) plays a vital role in GABA synthesis in Pinus pinaster seedlings. In our study, under $\mathrm{As}(\mathrm{V})$ challenged environment, GDH activity was increased in the test seedlings indicating enhanced production of glutamate from 2-oxoglutarate, a TCA cycle intermediate that subsequently converted to GABA by increased GAD activity during stress where GABA accumulation was found to be negatively correlated with growth retardation in the test seedlings. Pathare et al. (2013) reported an enhancement in GABA contents along with increased GAD activity in As(V) stressed root and shoot of two varieties of Brassica juncea viz., TPM- 1 and TM- 4 by integrating CNS metabolism and exerted tolerance against stress. Likewise, Carillo (2018) showed that GABA was accumulated under combined stress of salinity and high light conditions in durum wheat. The concentration of GABA was increased in the grains of two aromatic rice cultivars viz., Yuxiangyouzhan and Nongxiang 18 under all shading treatments (Mo et al. 2015). Elevated GDH activity in As(V) stressed rice cultivar MTU-1010 coincides with the increased activity of GDH in hydroponically grown seedlings of triticale under salt 
stress (Kwinta and Cal 2005). Kumar et al. (2000) also reported an increase in GDH activity in salt tolerant rice cv. CSR-1 compared to sensitive rice cv. CSR-3 and found to be one of the possible reason for growth promotion under salt stress. In the present study, we recorded positive correlation of GABA contents with both GAD activity $(r=0.603)$ and organic acids content $(r=0.207)$ under $A s(V)$ exposure in the test seedlings detected by Pearson's bivariate correlation analysis and suggesting that GABA and its regulatory enzymes play an essential role in regulating $\mathrm{C} / \mathrm{N}$ balance, supply succinate and/or NADH to TCA cycle, oxidative stress management and osmoregulation (Studart-Guimarães et al. 2007; Akcay et al. 2012). Upon formation, GABA again catabolized to succinate in mitochondrial matrix that principally acts as an electron donor to the mitochondrial electron transport chain (ETC) via two consecutive reactions catalyzed by GABA transaminase (GABA-T) and succinic semialdehyde dehydrogenase (SSADH) (Shelp et al. 2012b). In present investigation, GABA-T activity enhanced under As(V) stress for sustainable ATP production to conduct basic cellular metabolism under As challenged condition by continuous supply of succinate in complex II of mitochondrial ETC. Interestingly, upon both Si and Se applications in As(V) treated rice seedlings, we noted less accumulation in GABA contents and activity of its regulatory enzymes viz., GDH and GAD in contrast to $\mathrm{As}(\mathrm{V})$ treatment alone. The ameliorative effects were more pronounced during joint application of $\mathrm{Si}+\mathrm{As}(\mathrm{V})$ than $\mathrm{Se}+\mathrm{As}(\mathrm{V})$ indicating $\mathrm{Si}$ is more potential than $\mathrm{Se}$ in mitigating the $\mathrm{As}(\mathrm{V})$ induced stress in rice seedlings reducing GABA accumulation.

\subsection{Influence on endogenous polyamine contents}

Polyamines (PAs) viz., spermine (Spm), spermidine (Spd) and putrescine (Put) act as an endogenous plant growth regulators and have been described as secondary messengers that regulate signaling pathways and various responses against abiotic stresses (Kusano et al. 2008; Davies 2010; Pál et al. 2015; Mustafavi et al. 2018). In plants, PAs metabolism exhibited deep connection with other metabolic pathways viz., GABA production and generation of $\mathrm{H}_{2} \mathrm{O}_{2}$ via PA oxidation under biotic and abiotic stress responses (Freitas et al. 2017; Mellidou et al. 2017). Hussain et al. (2011) reported that PAs are prerequisite to reduce harmful effects caused by environmental stresses and protect several physiological activities of plants. Previous studies have reported that exogenous application of PAs under adverse conditions can lessen plasma membrane permeability, enhance chlorophylls content and reduce malondialdehyde (MDA) level (Zhang et al. 2010; Song et al. 2014). Mandal et al. (2013) reported that upon synthesis Put is converted back to Spm and Spd by sequential activities of spermidine synthase and spermine synthase, respectively. But very few reports were listed about the influence of endogenous PAs under heavy metal stress. We studied the levels of Put, Spd and Spm in the test seedlings treated with $\mathrm{As}(\mathrm{V})$ with or without $\mathrm{Si}$ and $\mathrm{Se}$. In $\mathrm{As}(\mathrm{V})$ exposed rice seedlings the Put level was increased while Spd and Spm levels were decreased where the effects were more conspicuous in shoot than root. Groppa \& Benavides (2008) reported that Put regulates the synthesis of both Spd and Spm in plants. Likewise, an enhancement in Put levels and reduction in both Spd and Spm levels were recorded in Ni stressed barley leaves (Molas and Chrząstek 2011). Pál et al. (2018) also demonstrated that in wheat leaves, Put accumulation under osmotic stress is the result of depletion in both Spd and Spm contents that corroborates with the present findings. In the study, during co-application of $\mathrm{As}(\mathrm{V})+\mathrm{Si}$ and $\mathrm{As}(\mathrm{V})+\mathrm{Se}$, Put contents was enhanced further while Spd and Spm contents were increased compared to $A s(V)$ treatment 
alone to ensure the stress tolerance activity of PAs in the test cultivar. Yang et al. (2013) demonstrated that Put contents increased while Spd and Spm contents decreased in the cotyledons of germinating Vicia fava L. under hypoxia. It has been noted that elevated level of Spd caused an improvement in heavy metal tolerance Wen et al. (2010). Similarly, Shao et al. (2015) reported that higher Spd contents exerted heat tolerance to alfalfa which are in correlation with our study where Si and Se supplementation in $\mathrm{As}(\mathrm{V})$ treated seedlings increased both Spd and Spm levels and lowered the retardation process of growth and development by sustainable restoration of respiratory cycle where Si application was found to be more effective compared to Se application [Fig. 15].

\section{Conclusion}

Present study demonstrated the role of $A s(V)$ to induce toxicity that caused harmful effects on the physiological attributes of rice seedlings. Both $\mathrm{Si}$ and Se supplementation in As(V) contaminated seedlings partially mitigated the toxic effects of $A s(V)$ by altering the tested physiological parameters. As $(V)$ treatment adversely affected the respiratory cycle by increasing the levels of organic acids (OAs) and decreasing the activities of its synthesizing enzymes in the test seedlings. Si amendment enhanced further the levels of OAs and activities of tested enzymes than Se amendment in $\mathrm{As}(\mathrm{V})$ treated seedlings, resulting acquisition of stress tolerance in the rice seedlings. The level of GABA along with activities of its regulatory enzymes were increased in the $\mathrm{As}(\mathrm{V})$ challenged rice seedlings. Si amendment lowered GABA accumulation and activities of its regulatory enzymes more than Se amendment in $\mathrm{As}(\mathrm{V})$ treated seedlings. The PAs content viz., Put, Spd and Spm were also affected under As(V) stress. During application of Si with $\mathrm{As}(\mathrm{V})$ and Se with $\mathrm{As}(\mathrm{V})$ the detrimental effects caused by $\mathrm{As}(\mathrm{V})$ on PAs accumulation was mitigated successfully by $\mathrm{Si}$. Accumulation of organic acids, PAs and reduction of GABA helped to overcome $\mathrm{As}(\mathrm{V})$ induced stress by altering osmoregulation, ionic balance, $\mathrm{C} / \mathrm{N}$ balance, membrane damage and oxidative stress management. Although a short term effect of $\mathrm{As}(\mathrm{V})$ on rice seedlings in laboratory condition may not elucidate the scenario that the plants face in field condition, but this study may help to decipher the role of $\mathrm{Si}$ and Se to combat $\mathrm{As}(\mathrm{V})$ stress. The results obtained from the study will help in future to achieve optimum growth and yield of rice plants grown in arsenic contaminated soil with the application of Si and Se enriched fertilizers.

\section{Abbreviations}

ACN

Acetonitrile; AMP - Adenosine monophosphate; ANOVA - Analysis of variance; As - Arsenic; As(V)Arsenate; $\mathrm{As}(\mathrm{III})$ - Arsenite; a-KGDH-a-ketoglutarate dehydrogenase; $\mathrm{BSA}$-Bovine serum albumin; $\mathrm{CaCl}_{2}$ Calcium chloride; Co-A-Coenzyme $\mathrm{A} ; \mathrm{CH}_{3} \mathrm{COOC}_{2} \mathrm{H}_{5}$ - Ethyl acetate; $\mathrm{C} / \mathrm{N}$-Carbon/Nitrogen; CNS-Carbon nitrogen sulphur; CS-Citrate synthase; DNPH - 2,4-Dinitrophenylhydrazine; DTT-Dithiothreitol; DTNB 5,5'-dithiobis-(2-nitrobenzoic acid); EDTA - Ethylenediaminetetraacetic acid; GABA- $\gamma$-aminobutyric acid; GABA-T-GABA transaminase; GAD-Glutamate decarboxylase; GDH-Glutamate dehydrogenase; $\mathrm{h}$-hour; $\mathrm{H}_{2} \mathrm{SO}_{4}$ - Sulfuric acid; $\mathrm{HCl}$-Hydrochloric acid; $\mathrm{HClO}_{4}$-Perchloric acid; HEPES - 4-(2-hydroxyethyl)-1- 
piperazineethanesulfonic acid; HPLC-High performance liquid chromatography; HSD-Honest significant difference; ICDH-Isocitrate dehydrogenase; INT-Iodonitrotetrazolium or 2-(4-iodophenyl)-3-(4nitrophenyl)-5-phenyl-2H-tetrazolium; $\mathrm{KOH}$-Potassium hydroxide; $\mathrm{MDH}-$ Malate dehydrogenase; minminutes; $\mathrm{MgCl}_{2}$ - Magnesium chloride; $\mathrm{MnSO}_{4}$ - Manganese(II) sulfate; MOPS - 3-(Nmorpholino)propanesulfonic acid; $\mathrm{Na}_{2} \mathrm{CO}_{3}$-Sodium carbonate; NAD - Nicotinamide adenine dinucleotide; $\mathrm{NADPH}$ - Nicotinamide adenine dinucleotide phosphate hydrogen; $\mathrm{NaH}_{2} \mathrm{PO}_{4}$ - Monosodium phosphate; $\mathrm{NaOCl}$-Sodium hypochlorite; $\mathrm{NaOH}$-Sodium hydroxide; $\mathrm{NH}_{4} \mathrm{OH}$ - Ammonium hydroxide; $\left(\mathrm{NH}_{4}\right)_{2} \mathrm{SO}_{4}$ Ammonium sulfate; NO-Nitric oxide; OA-Organic acid; OAA-Oxaloacetic acid; OD-Optical density; PAsPolyamines; PDH-Pyruvate dehydrogenase; Put-Putrescine; PVP-Polyvinylpyrrolidone; RFs-Retention factors; ROS-Reactive oxygen species; rpm - revolutions per minute; $\mathrm{s}$-seconds; Se-Selenium; SDHSuccinate dehydrogenase; Si - Silicon; SPD - Spermidine; SPM-Spermine; SPSS - Statistical package for the social sciences; TCA-Trichloroacetic acid; TLC-Thin layer chromatography; TPP - Thiamine pyrophosphate; $\mathrm{UQH}_{2}-$ Ubiquinol; UQ-Ubiquinone.

\section{Declarations}

\section{Acknowledgement}

The authors would acknowledge the Department of Science \& Technology, Government of India for providing DST-Inspire Fellowship (No. DST/INSPIRE Fellowship/2015/IF150003) to S.D. We are thankful to the Centre for advanced study, Department of Botany, University of Calcutta for providing the infrastructure facility.

\section{Conflict of interest statements}

Ethical approval: Not Applicable, since no human or animal participants are used in this study. .

Conflict of interest: The authors declare that they have no conflict of interest.

\section{Author's contribution}

SD designed and carried out the experiments, did all data analysis and drafted the manuscript. BM helped in drafting of the manuscript. AKB conceived the study, helped to design experiments, analyzed results and finalized the manuscript.

\section{References}

1. Adrees M, Ali S, Rizwan M, Zia-Ur-Rehman M, Ibrahim M, Abbas F, Farid M, Qayyum MF, Irshad MK (2015) Mechanisms of silicon-mediated alleviation of heavy metal toxicity in plants: a review. Ecotoxicol Environ Saf 119:186-197

2. Akc, ay N, Bor M, Karabudak T, O" zdemir F, Tu“rkan I (2012) Contribution of gamma amino butyric acid (GABA) to salt stress responses of Nicotiana sylvestris CMSII mutant and wild type plants. $J$ 
Plant Physiol 169:452-458

3. Akihiro T, Koike S, Tani R, Tominaga T, Watanabe S, Lijima Y, Aoki K, Shibata D, Ashihara H, Matsukura C, Akama K, Fujimura T, Ezura H (2008) Biochemical mechanism on GABA accumulation during fruit development in tomato. Plant Cell Physiol 49(9):1378-1389

4. Allan WL, Simpson JP, Clark SM, Shelp BJ (2008) y-hydroxybutyrate accumulation in Arabidopsis and tobacco plants is a general response to abiotic stress: putative regulation by redox balance and glyoxylate reductase isoforms. J Exp Bot 59:2555-2564

5. Ahmad A, Khan WU, Ali Shah A, Yasin NA, Naz S, Ali A, Tahir A, Iram Batool A (2021) Synergistic effects of nitric oxide and silicon on promoting plant growth, oxidative stress tolerance and reduction of arsenic uptake in Brassica juncea. Chemosphere 262:128384

6. Araújo WL, Martins AO, Fernie AR, Tohge T (2014) 2-Oxoglutarate: linking TCA cycle function with amino acid, glucosinolate, flavonoid, alkaloid, and gibberellin biosynthesis. Front Plant Sci 5:552

7. Bansal P, Sharma P, Goyal V (2002) Impact of lead and cadmium on enzyme of citric acid cycle in germinating pea seeds. Biol Plant 45:125-127

8. Bartyzel I, Pelczar K, Paszkowski A (2003) Functioning of the gamma-aminobutyrate pathway in wheat seedlings affected by osmotic stress. Biol Plant 47:221-225

9. Bergmeyer H, Gawwehn K, Grassl M (1974) Enzymes as biochemical reagents. In: Bergmeyer H (ed) Methods of Enzymatic Analysis. Academic Press, New York, pp 425-556

10. Bogdan K, Schenk MK (2008) Arsenic in rice (Oryza sativa L.) related to dynamics of arsenic and silicic acid in paddy soils. Environ Sci Technol 42(21):7885-7890

11. Bor M, Seckin B, Ozgur R, Yilmaz O, Ozdemir F, Turkan I (2009) Comparative effects of drought, salt, heavy metal and heat stresses on gamma-aminobutryric acid (GABA) levels of sesame (Sesamum indicum L.). Acta Physiol Plant 31:655-659

12. Bouche N, Fromm H (2004) GABA in plants: Just ametabolite? Trends Plant Sci 9:110-115

13. Bouthour D, Hajjaji-Nasraoui A, Saafi L, Gouia H, Chaffei-Haouari C (2012) Effects of NaCl on growth and activity of enzymes involved in carbon metabolism in leaves of tobacco (Nicotiana rustica). Afr J Biotechnol 11:12619-12629

14. Bown AW, Shelp BJ (1997) The metabolism and functions of $Y$-aminobutyric acid. Plant Physiol 115:1-5

15. Carillo P (2018) GABA Shunt in Durum Wheat. Front. Plant Sci 100(9): pages 100

16. Cavalcanti JH, Esteves-Ferreira AA, Quinhones CG, Pereira-Lima IA, Nunes-Nesi A, Fernie AR, Araújo WL (2014) Evolution and functional implications of the tricarboxylic acid cycle as revealed by phylogenetic analysis. Genome Biol Evol 6:2830-2848

17. Centeno DC, Osorio S, Nunes-Nesi A, Bertolo ALF, Carneiro RT, Araújo WL, Steinhauser MC, Michalska J, Rohrmann J, Geigenberger P, Oliver SN, Stitt M, Carrari F, Rose JKC, Fernie AR (2011) Malate plays a crucial role in starch metabolism, ripening, and soluble solid content of tomato fruit and affects postharvest softening. Plant Cell 23:162-184 
18. Cuevas JC, López-Cobollo R, Alcázar R, Zarza X, Koncz C, Altabella T, Salinas J, Tiburcio AF, Ferrando A (2008) Putrescine is involved in Arabidopsis freezing tolerance and cold acclimation by regulating abscisic acid levels in response to low temperature. Plant Physiol 148(2):1094-1105

19. Das B, Rahman MM, Nayak B, Pal A, Chowdhury UK, Mukherjee SC, Saha KC, Pati S, Quamruzzaman Q, Chakraborti D (2009) Groundwater arsenic contamination, its health effects and approach for mitigation in West Bengal, India and Bangladesh. Water Expo Health 1(1):5-21

20. Das D, Pradhan S, Biswas AK (2011) Influence of selenium on growth and metabolism in rice (Oryza sativa L.) and its possible interaction with sulphate. Indian J Plant Physiol 16(1):35-48

21. Das S, Majumder B, Biswas AK (2018) Modulation of growth, ascorbate-glutathione cycle and thiol metabolism in rice (Oryza sativa L. Cv. MTU-1010) seedlings by arsenic and silicon. Ecotoxicol 27(10):1387-1403

22. Davies PJ (2010) The Plant Hormones: Their Nature, Occurrence, and Functions. In: Davies PJ (ed) Plant Hormones. Springer, Dordrecht

23. Dey TK, Banerjee P, Bakshi M, Kar A, Ghosh S (2014) Groundwater arsenic contamination in west bengal:current scenario, effects and probable ways of mitigation. Int Lett Nat Sci 13:45-58

24. Duan J, Li J, Guo S, Kang YJ (2008) Exogenous spermidine affects polyamine metabolism in salinity-stressed Cucumis sativus roots and enhances short-term salinity tolerance. Plant Physiol 165(15):1620-1635

25. Edreva AM, Velikova VB, Tsonev TD (2007) Phenylamides in plants. Russ J Plant Physiol 54(3):287301

26. Fait A, Fromm H, Walter D, Galili G, Fernie AR (2008) Highway or byway: the metabolic role of the GABA shunt in plants. Trends Plant Sci 13:14-19

27. Freitas VS, Miranda RDS, Costa JH, Al E (2017) Ethylene triggers salt tolerance in maize genotypes by modulating polyamine catabolism enzymes associated with $\mathrm{H}_{2} \mathrm{O}_{2}$ production. Environ Exp Bot 145:75-86

28. Fleck AT, Mattusch J, Schenk MK (2013) Silicon decreases the arsenic level in rice grain by limiting arsenite transport. J Plant Nutr Soil Sci 176:785-794

29. Flores HE, Galston AW (1982) Analysis of polyamines in higher plants by high performance liquid chromatography. Plant Physiol 69(3):701-706

30. Green JD, Narahara HT (1980) Assay of succinate dehydrogenase activity by the tetrazolium method: evaluation of an improved technique in skeletal muscle fractions. J Histochem Cytochem 28(5):408-412

31. Groppa MD, Benavides MP (2008) Polyamines and abiotic stress: recent advances. Amino Acids 34:35-45

32. Gupta K, Dey A, Gupta B (2013) Plant polyamines in abiotic stress responses. Acta Physiol Plant 35:2015-2036 
33. Hasanuzzaman M, Nahar K, Fujita M (2014) Silicon and Selenium. Emerging Technologies and Management of Crop Stress Tolerance, pp 377-422

34. Hasanuzzaman M, Nahar K, Anee TI, Fujita M (2017) Exogenous silicon attenuates cadmiuminduced oxidative stress in Brassica napus L. by modulating AsA-GSH pathway and glyoxalase system. Front Plant Sci 8

35. Hasanuzzaman M, Bhuyan MHMB, Raza A, Hawrylak-Nowak B, Matraszek-Gawron R, Mahmud JA, Nahar K, Fujita M (2020) Selenium in Plants: Boon or Bane? Environ Exp Bot 104170

36. He L, Li B, Lu X, Yuan L, Yang Y, Yuan Y, Du J, Guo S (2015) The effect of exogenous calcium on mitochondria, respiratory metabolism enzymes and ion transport in cucumber roots under hypoxia. Sci Rep 5:11391

37. Hoagland DR, Arnon DI (1950) The water culture method for growing plants without soil. Calif Agric Exp Sta 347:1-32

38. Hodges M (2002) Enzyme redundancy and the importance of 2-oxoglutarate in plant ammonium assimilation. J Exp Bot 53:905-916

39. Hui YG (2012) Alkali stress induced the accumulation and secretion of organic acids in wheat. Afric J Agric Res 7:2844-2852

40. Hussain S, Mumtaz M, Manzoor S, Shuxian L, Ahmed I, Skalicky M, Brestic M, Rastogi A, Ulhassan Z, Shafiq I, Allakhverdiev SI, Khurshid H, Yang W, Liu W (2021) Foliar application of silicon improves growth of soybean by enhancing carbon metabolism under shading conditions. Plant Physiol Biochem 159:43-52

41. Hussain SS, Ali M, Ahmad M, Siddique KH (2011) Polyamines: natural and engineered abiotic and biotic stress tolerance in plants. Biotech Advan 29(3):300-311

42. Hummel JP (1949) The fluorometric determination of malic acid. J Biol Chem 180:1225-1228

43. Kitaoka S, Nakano Y (1969) Colorimetric determination of omega-amino acids. J Biol Chem 66:8794

44. Kumar RG, Shah K, Dubey RS (2000) Salinity induced behavorial changes in malate dehydrogenase and glutamate dehydrogenase activities in rice seedlings of differing salt tolerance. Plant Sci 156:23-34

45. Kusano T, Berberich T, Tateda C, Takahashi Y (2008) Polyamines: essential factors for growth and survival. Planta 228:367-381

46. Kwinta J, Cal K (2005) Effects of salinity stress on the activity of glutamine synthetase and glutamate dehydrogenase in Triticale seedlings. Pol J Environ Stud 14:125-130

47. Li Z, Yu J, Peng Y, Huang B (2016) Metabolic pathways regulated by Y-aminobutyric acid (GABA) contributing to heat tolerance in creeping bentgrass (Agrostis stolonifera). Sci Rep 6:30338

48. Logoteta B, Xu XY, Macnair MR, McGrath SP, Zhao FJ (2009) Arsenite efflux is not enhanced in the arsenate-tolerant phenotype of Holcus lanatus. New Phytol 183:340-348 
49. Lowry OH, Rosebrough NJ, Farr AL, Randall RJ (1951) Protein measurement with the folin phenol reagent. J Biol Chem 193:265-275

50. López-Millán AF, Sagardoy R, Solanas M, Abadía A, Abadía J (2009) Cadmium toxicity in tomato (Lycopersicon esculentum) plants grown in hydroponics. Environ Exp Bot 65:376-385

51. Lu LL, Tian SK, Yang XE, Peng HY, Li TQ (2013) Improved cadmium uptake and accumulation in the hyperaccumulator Sedum alfredii: the impact of citric acid and tartaric acid. J Zhejiang Univ Sci B 14:106-114

52. Mae N, Makino Y, Oshita S, Kawagoe Y, Tanaka A et al (2013) Accumulation mechanism of of $Y^{-}$ aminobutyric acid in tomatoes (Solanum lycopersicum L.) under low $\mathrm{O}_{2}$ with and without $\mathrm{CO}_{2}$. J Agric Food Chem 60:1013-1019

53. Mahmud JA, Hasanuzzaman M, Nahar K, Rahman A, Hossain MS, Fujita M (2017) y-aminobutyric acid (GABA) confers chromium stress tolerance in Brassica juncea L. by modulating the antioxidant defense and glyoxalase systems. Ecotoxicol 26(5):675-690

54. Mandal S, Mandal A, Johansson HE, Orjalo AV, Park MH (2013) Depletion of cellular polyamines, spermidine and spermine, causes a total arrest in translation and growth in mammalian cells. Proceedings of the National Academy of Sciences 110(6):2169-2174

55. Marino D, Dunand C, Puppo A, Pauly N (2012) A burst of plant NADPH oxidases. Trends Plant Sci $17(1): 9-15$

56. Meharg AA, Hartley-Whitaker J (2002) Arsenic uptake and metabolism in arsenic resistant and nonresistant plant species. New Phytol 154(1):29-43

57. Mellidou I, Karamanoli K, Beris D, Al E (2017) Underexpression of apoplastic polyamine oxidase improves thermotolerance in Nicotiana tabacum. J Plant Physiol 218:171-174

58. Michaeli S, Fait A, Lagor K, Nunes-Nesi A, Grillich N, Yellin A et al (2011) A mitochondrial GABA permease connects the GABA shunt and the TCA cycle, and is essential for normal carbon metabolism. Plant J 67:485-498

59. Millar AH, Hill SA, Leaver CJ (1999) Plant mitochondrial 2-oxoglutarate dehydrogenase complex: purification and characterization in potato. Biochem $\mathrm{J}$ 15:327-334

60. Mo Z, Li W, Pan S, Fitzgerald TL, Xiao F, Tang Y, Wang Y, Duan M, Tian H, Tang X (2015) Shading during the grain filling period increases 2-acetyl-1-pyrroline content in fragrant rice. Rice 8:9

61. Molas J, Chrząstek M (2011) Comparison of polyamine content in leaves of barley plants grown in nickel stress conditions, caused by inorganic and chelatic nickel. Proceedings of Ecopole 5:77-81

62. Molina-Rueda JJ, Pascual MB, Cánovas FM, Gallardo F (2010) Characterization and developmental expression of a glutamate decarboxylase from maritime pine. Planta 232:1471-1483

63. Mustafavi SH, Badi HN, Sekara A, Al E (2018) Polyamines and their possible mechanisms involved in plant physiological processes and elicitation of secondary metabolites. Acta Physiol Plant 40:102

64. Nayyar H, Kaur R, Kaur S, Singh R (2014) Y-Aminobutyric acid (GABA) imparts partial protection from heat stress injury to rice seedlings by improving leaf turgor and upregulating osmoprotectants and 
antioxidants. J Plant Growth Regul 33:408-419

65. Nunes-Nesi A, Sulpice R, Gibon Y, Fernie AR (2008) The enigmatic contribution of mitochondrial function in photosynthesis. J Exp Bot 59:1675-1684

66. Nunes-Nesi A, Araújo WL, Fernie AR (2011) Targeting mitochondrial metabolism and machinery asameans to enhance photosynthesis. Plant Physiol 155:101-107

67. Nunes-Nesi A, Araujo WL, Obata T, Fernie AR (2013) Regulation of the mitochondrial tricarboxylic acid cycle. Curr Opin Plant Biol 16:335-343

68. Oburger E, Kirk GJD, Wenzel WW, Puschenreiter M (2009) Interactive effects of organic acids in the rhizosphere. Soil Biol Biochem 41:449-457

69. Pál M, Szalai G, Janda T (2015) Speculation: polyamines are important in abiotic stress signaling. Plant Sci 237:16-23

70. Pál M, Tajti J, Szalai G, Peeva V, Végh B, Janda T (2018) Interaction of polyamines, abscisic acid and proline under osmotic stress in the leaves of wheat plants. Sci Rep 8:12839

71. Palomo L, Claassen N, Jones DL (2006) Differential mobilization of $P$ in the maize rhizosphere by citric and potassium citrate. Soil Biol Biochem 38:683-692

72. Pathare V, Srivastava S, Suprasanna P (2013) Evaluation of effects of arsenic on carbon, nitrogen, and sulfur metabolism in two contrasting varieties of Brassica juncea. Acta Physiol Plant 35:3377

73. Pontigo S, Godoy K, Jiménez H, Gutiérrez-Moraga A, Mora MD, Cartes P (2017) Silicon-mediated alleviation of aluminum toxicity by modulation of $\mathrm{Al} / \mathrm{Si}$ uptake and antioxidant performance in ryegrass plants. Front Plant Sci 8:642

74. Quinlan CL, Orr AL, Perevoshchikova IV, Treberg JR, Ackrell BA, Brand MD (2012) Mitochondrial complex-II can generate reactive oxygen species at high rates in both the forward and reverse reactions. J Biol Chem 287(32):27255-27264

75. Radhakrishnan R, Lee IJ (2013) Spermine promotes acclimation to osmotic stress by modifying antioxidant, abscisic acid, and jasmonic acid signals in soybean. J Plant Growth Regul 32:22-30

76. Rai PK, Lee SS, Zhang M, Tsang YF, Kim KH (2019) Heavy metals in food crops: Health risks, fate, mechanisms, and management. Environ Int 125:365-385

77. Redmond JH, Tseng A (1979) High-pressure liquid chromatographic determination of putrescine, cadaverine, spermidine and spermine. J Chromatogr A 170(2):479-481

78. Renault H, Roussel V, Amrani EA, Arzel M, Renault D et al (2010) The Arabidopsis pop2-1 mutant reveals the involvement of GABA transaminase in salt stress tolerance. BMC Plant Biol 10:1-16

79. Renault H, Amrani AE, Berger A, Mouille G, Soubigou-Taconnat L, Bouchereau A, Deleu C (2013) Gamma- Aminobutyric acid transaminase deficiency impairs central carbon metabolism and leads to cell wall defects during salt stress in Arabidopsis roots. Plant Cell Environ 36:1009-1018

80. Rolin D, Baldet P, Just D, Chevalier C, Biran M, Raymond P (2000) NMR study of low subcellular pH during the development of cherry tomato fruit. Aust J Plant Physiol 27:61-69 
81. Sadasivam S, Manickam A (2008) Biochemical Methods, third edn. New Age International Publishers, New Delhi

82. Saffran M, Denstedt O (1948) A rapid method for determination of citric acid. J Biol Chem 175:849855

83. Saha P, Kunda P, Biswas AK (2012) Influence of sodium chloride on the regulation of Krebs cycle intermediates and enzymes of respiratory chain in Mungbean (Vigna radiata L.) seedlings. Plant Physiol Biochem 60:214-222

84. Samikkannu T, Chen $\mathrm{CH}$, Yih LH, Wang AS et al (2003) Reactive oxygen species are involved in arsenic trioxide inhibition of pyruvate dehydrogenase activity. Chem Res Toxicol 16:409-414

85. Seifikalhor M, Aliniaeifard S, Bernard F, Seif M, Latifi M, Hassani B, Didaran F, Bosacchi M, Rezadoost $\mathrm{H}, \mathrm{Li} \mathrm{T}(2020) \mathrm{Y}$-Aminobutyric acid confers cadmium tolerance in maize plants by concerted regulation of polyamine metabolism and antioxidant defense systems. Sci Rep 10:3356

86. Shao Y, Jiang L, Zhang D, Ma L, Li C (2011) Effects of arsenic, cadmium and lead on growth and respiratory enzymes activity in wheat seedlings. Afr J Agri Res 6:4505-4512

87. Shao CG, Wang H, Yu-Fen BI (2015) Relationship between endogenous polyamines and tolerance in Medicago sativa L. under heat stress. Acta Agrestia Sinica 23:1214-1219

88. Shelp BJ, Bozzo GG, Trobacher CP, Zarei A, Deyman KL, Brikis CJ (2012a) Hypothesis/review: contribution of putrescine to 4-aminobutyrate (GABA) production in response to abiotic stress. Plant Sci 193-194:130-135

89. Shelp BJ, Mullen RT, Waller JC (2012b) Compartmentation of GABA metabolism raises intriguing questions. Trends Plant Sci 17:57-59

90. Shen S, Li XF, Cullen WR, Weinfeld M, Le XC (2013) Arsenic binding to proteins. Chem Rev 113:77697792

91. Sienkiewicz-Porzucek A, Sulpice R, Osorio S, Krahnert I, Leisse A, Urbanczyk-Wochniak E, Hodges M, Fernie AR, NunesNesi A (2010) Mild reductions in mitochondrial NAD dependent isocitrate dehydrogenase activity result in altered nitrate assimilation and pigmentation but do not impact growth. Mol Plant 3:156-173

92. Singh VP, Tripathi DK, Kumar D, Chauhan DK (2011) Influence of exogenous silicon addition on aluminium tolerance in rice seedlings. Biol Trace Elem Res 144:1260-1274

93. Song F, Han X, Zhu X, Herbert SJ (2011) Response to water stress of soil enzymes and root exudates from drought and non-drought tolerant corn hybrids at different growth stages. Can J Soil Sci 92(3):501-507

94. Song Y, Diao Q, Qi H (2014) Polyamine metabolism and biosynthetic genes expression in tomato (Lycopersicon esculentum Mill.) seedlings during cold acclimation. Plant Growth Regul 75(1):21-32

95. Soundararajan P, Sivanesan I, Jana S, Jeong BR (2014) Influence of silicon supplementation on the growth and tolerance to high temperature in Salvia splendens. Hort Environ Biotechnol 55:271-279 
96. Srere PA (1969) Citrate synthase: [EC 4.1.3.7. Citrate oxaloacetate-lyase (CoA-acetylating)]. Methods Enzymol 13:3-11

97. Studart-Guimaraes C, Fait A, Nunes-Nesi A, Carrari F, Usadel B, Fernie AR (2007) Reduced expression of succinyl-coenzyme A ligase can be compensated for by up-regulation of the $\gamma$-aminobutyrate shunt in illuminated tomato leaves. Plant Physiol 145:626-639

98. Swaine DJ (1955) The trace element content of soils. Report of the Commonwealth Bureau of Soil Science, London, p. 48

99. Sweetman C, Deluc LG, Cramer GR, Ford CM, Soole KL (2009) Regulation of malate metabolism in grape berry and other developing fruits. Phytochem 70:1329-1344

100. Tripathi DK, Singh S, Singh VP, Prasad SM, Dubey NK, Chauhan DK (2016) Silicon nanoparticles more effectively alleviated UV-B stress than silicon in wheat (Triticum aestivum) seedlings. Plant Physiol Biochem 110:70-80

101. Ulhassan Z, Gill RA, Huang H, Ali S, Mwamba TM, Ali B, Huang Q, Hamid Y, Khan AR, Wang J, Zhou W (2019a) Selenium mitigates the chromium toxicity in Brassicca napus L. by ameliorating nutrients uptake, amino acids metabolism and antioxidant defense system. Plant Physiol Biochem. doi:10.1016/j.plaphy.2019.10.035

102. Ulhassan Z, Gill RA, Ali S, Mwamba TM, Ali B, Wang J, Huang Q, Aziz R, Zhou W (2019b) Dual behavior of selenium: Insights into physio-biochemical, anatomical and molecular analyses of four Brassica napus cultivars. Chemosphere 225:329-341

103. Valle AB, Panek AD, Mattoon JR (1978) Colorimetric determination of succinic acid using yeast succinate dehydrogenase. Anal Biochem 91(2):583-599

104. Vijayakumari K, Puthur JT (2016) Y-Aminobutyric acid (GABA) priming enhances the osmotic stress tolerance in Piper nigrum Linn. plants subjected to PEG-induced stress. Plant Growth Regul 78:57-67

105. Wang GF, Li WQ, Li WY, Wu GL, Zhou CY, Chen KM (2013) Characterization of rice NADPH oxidase genes and their expression under various environmental conditions. Int J Mol Sci 14:9440-9458

106. Wen XP, Ban Y, Inoue H, Matsuda N, Moriguchi T (2010) Spermidine levels are implicated in heavy metal tolerance in a spermidine synthase overexpressing transgenic European pear by exerting antioxidant activities. Transgenic Res 19:91-103

107. Wi SJ, Kim SJ, Kim WT, Park KY (2014) Constitutive S-adenosylmethionine decarboxylase gene expression increases drought tolerance through inhibition of reactive oxygen species accumulation in Arabidopsis. Planta 239(5):979-988

108. Williams M, Randall DD (1979) Pyruvate dehydrogenase complex from chloroplasts of Pisum sativum L. Plant Physiol 64:1099-1103

109. Xing SG, Jun YB, Hau ZW, Liang LY (2007) Higher accumulation of $Y$-aminobutyric acid induced by salt stress through stimulating the activity of diamine oxidases in Glycine max (L.) Merr. Roots. Plant Physiol Biochem 45(8):560-566

110. Xu C, Wu X, Zhang H (2009) Impact of D-Arg on drought resistance and endogenous polyamines in mycorrhizal Pinus massoniana. J Nanjing Forestry Univ 33:019-023 
111. Xu A, Mu C, Li X, Lin J, Li Y, Mu Y (2013) Salt and alkali stresses effects on contents of organic acids components in wheat seedlings. J Plant Nutr 36:1056-1064

112. Yang J, Zhang J, Liu K, Wang Z, Liu L (2007) Involvement of polyamines in the drought resistance of rice. J Exp Bot 58(6):1545-1555

113. Yang R, Guo Q, Gu Z (2013) GABA shunt and polyamine degradation pathway on Y-aminobutyric acid accumulation in germinating fava bean (Vicia faba L.) under hypoxia. Food Chem 136:152-159

114. Yazdanparast JR, Qujeo D (1994) Significant changes in the activity of gaba transaminase and succinate semialdehyde dehydrogenase of mouse hypothalamus following peripheral injection of cholecystokinin-8 and/or caerulein. Med J Islam Repub Iran 7:263-268

115. Zhang Z, Liu S, Hao S, Liu S (2010) Grafting increases the copper tolerance of cucumber seedlings by improvement of polyamine contents and enhancement of antioxidant enzymes activity. Agric Sci China 9(7):985-994

116. Zhang J, Zhang Y, Du Y, Chen S, Tang H (2011) Dynamic metabonomic responses of tobacco (Nicotiana tabacum) plants to salt stress. J Proteome Res 10(4):1904-1914

117. Zhou J, Tian X, Qiao L, Qin P (2012) Respiratory enzyme activity and regulation of respiration pathway in seashore mallow (Kosteletzkya virginica) seedlings under waterlogging conditions. Aust J Crop Sci 6:756-762

118. Zwolak I, Zaporowska H (2012) Selenium interactions and toxicity: a review. Cell Biol Toxicol 28(1):31-46

\section{Tables}

Due to technical limitations, Table 1 and Table 2 are only available as a download in the supplementary files section.

\section{Figures}
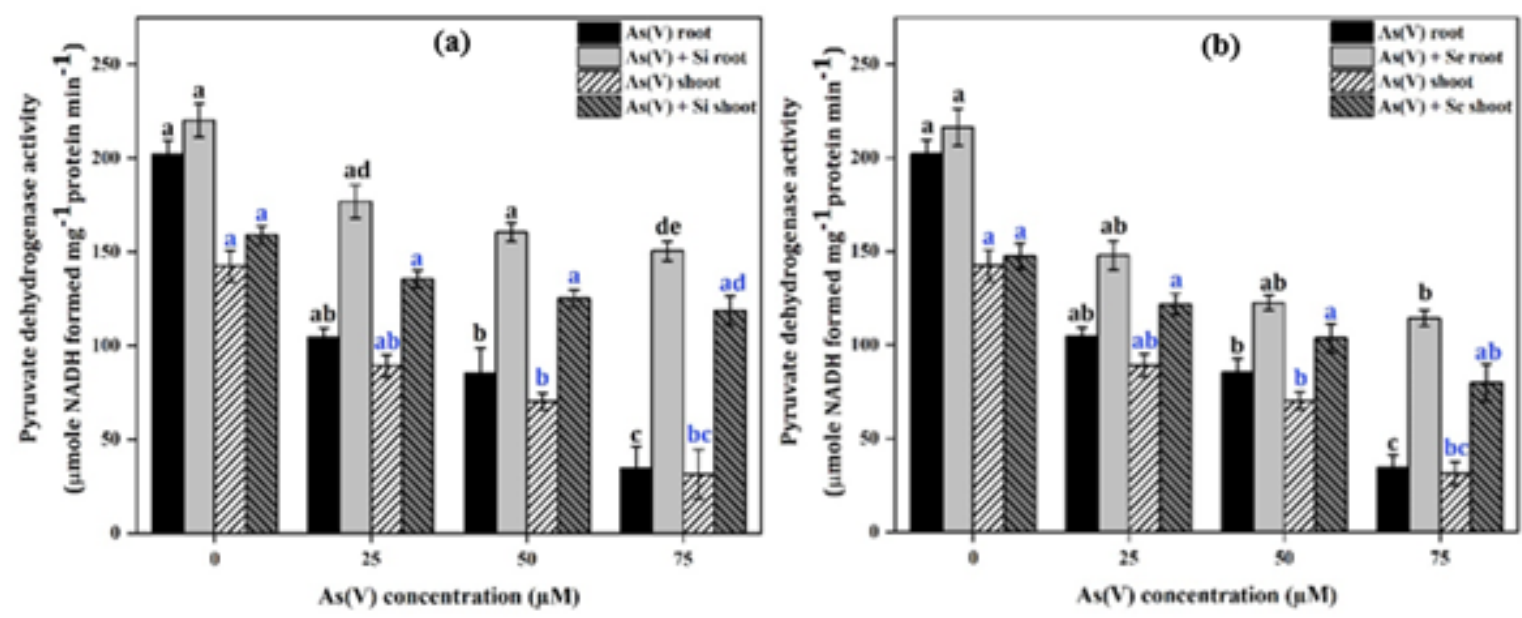

Figure 1 
Influence of increasing concentrations of $\mathrm{As}(\mathrm{V})$ with or without $\mathrm{Si}(\mathrm{a})$ and $\mathrm{Se}(\mathrm{b})$ on PDH activity in 3 weeks old rice seedlings. Different letterings are used to indicate statistically significant treatments differences, at $5 \%$ level of significance, for both roots and shoots separately.
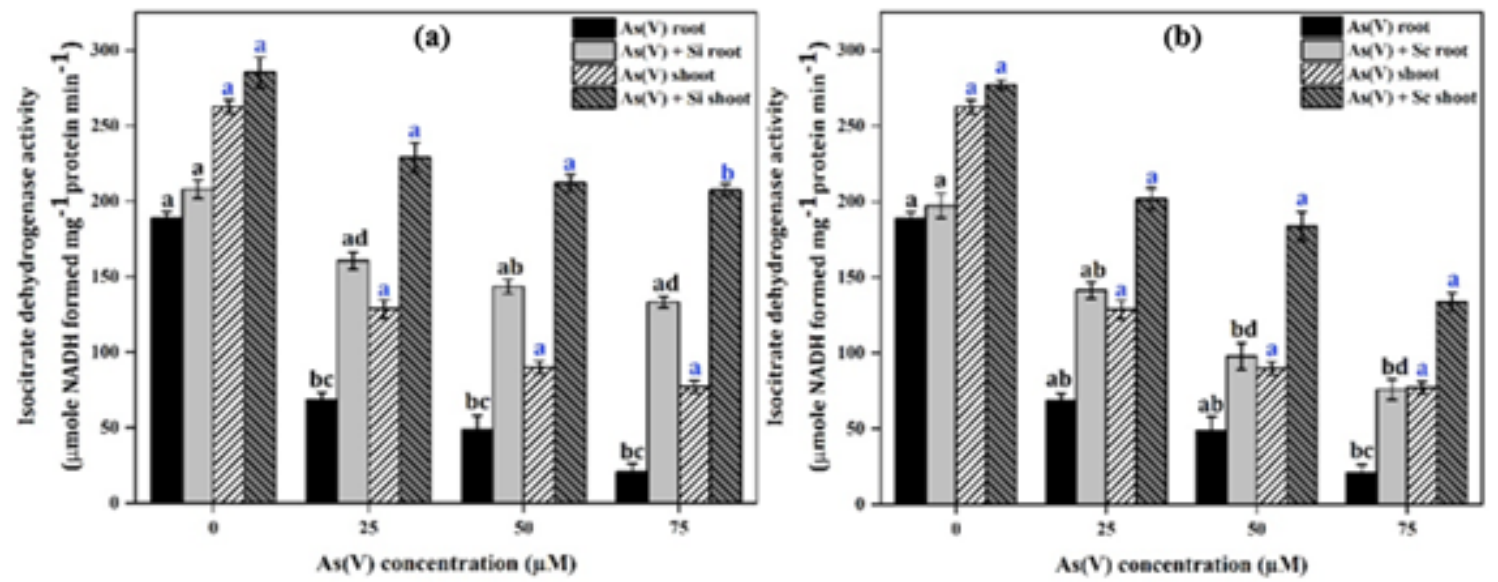

Figure 2

Influence of increasing concentrations of $\mathrm{As}(\mathrm{V})$ with or without $\mathrm{Si}(\mathrm{a})$ and $\mathrm{Se}(\mathrm{b})$ on ICDH activity in 3 weeks old rice seedlings. Different letterings are used to indicate statistically significant treatments differences, at $5 \%$ level of significance, for both roots and shoots separately.
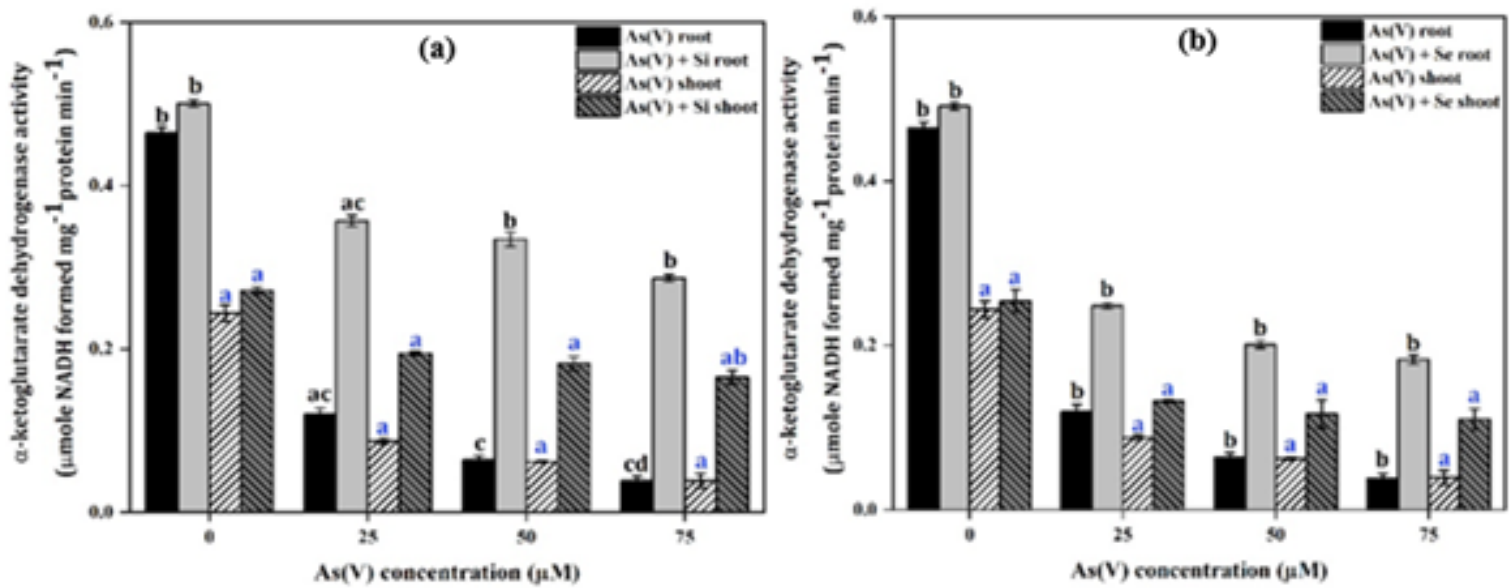

Figure 3

Influence of increasing concentrations of $\mathrm{As}(\mathrm{V})$ with or without $\mathrm{Si}(\mathrm{a})$ and $\mathrm{Se}(\mathrm{b})$ on a-KGDH activity in 3 weeks old rice seedlings. Different letterings are used to indicate statistically significant treatments differences, at $5 \%$ level of significance, for both roots and shoots separately. 

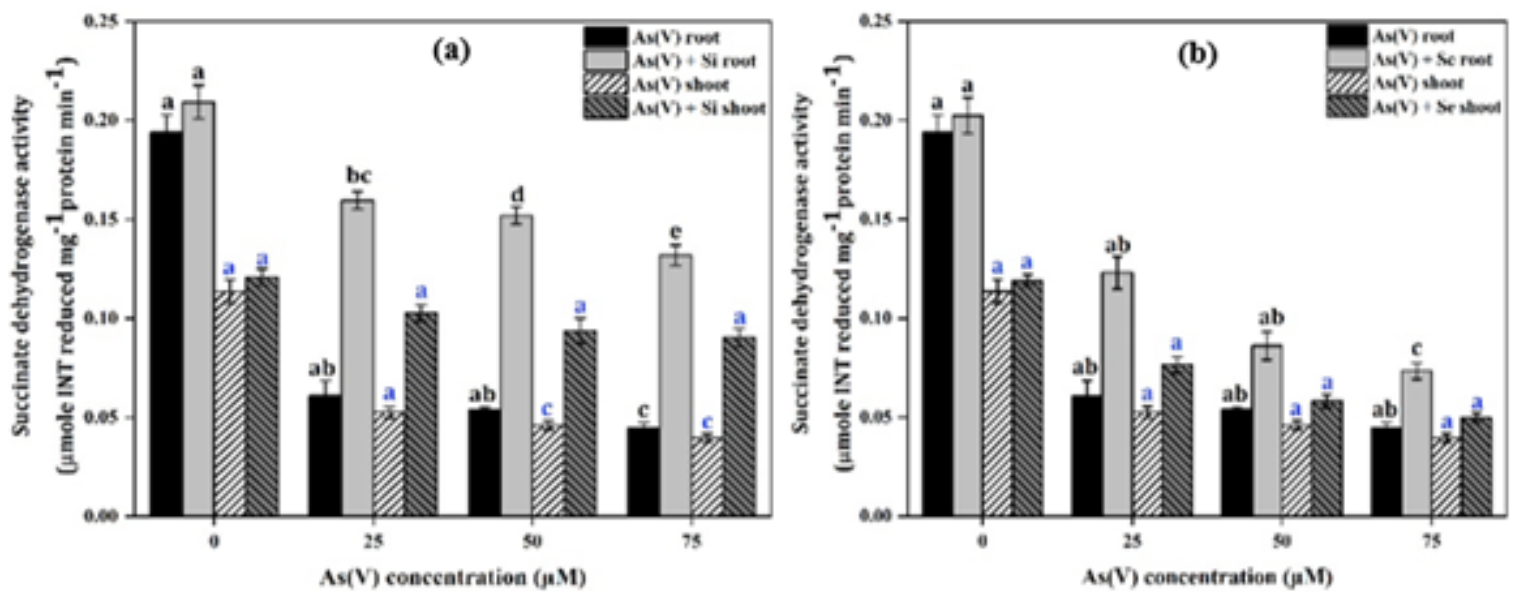

Figure 4

Influence of increasing concentrations of $\mathrm{As}(\mathrm{V})$ with or without $\mathrm{Si}(\mathrm{a})$ and $\mathrm{Se}(\mathrm{b})$ on SDH activity in 3 weeks old rice seedlings. Different letterings are used to indicate statistically significant treatments differences, at $5 \%$ level of significance, for both roots and shoots separately.
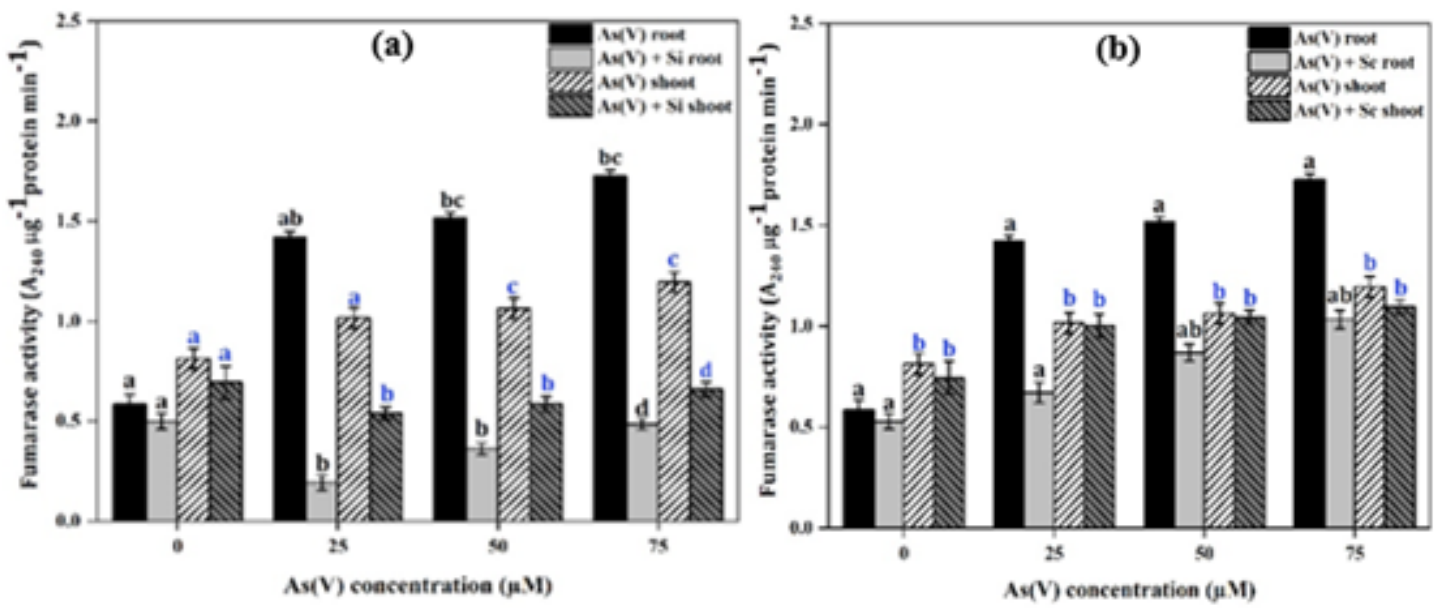

Figure 5

Influence of increasing concentrations of $\mathrm{As}(\mathrm{V})$ with or without $\mathrm{Si}(\mathrm{a})$ and $\mathrm{Se}(\mathrm{b})$ on fumarase activity in 3 weeks old rice seedlings. Different letterings are used to indicate statistically significant treatments differences, at $5 \%$ level of significance, for both roots and shoots separately. 

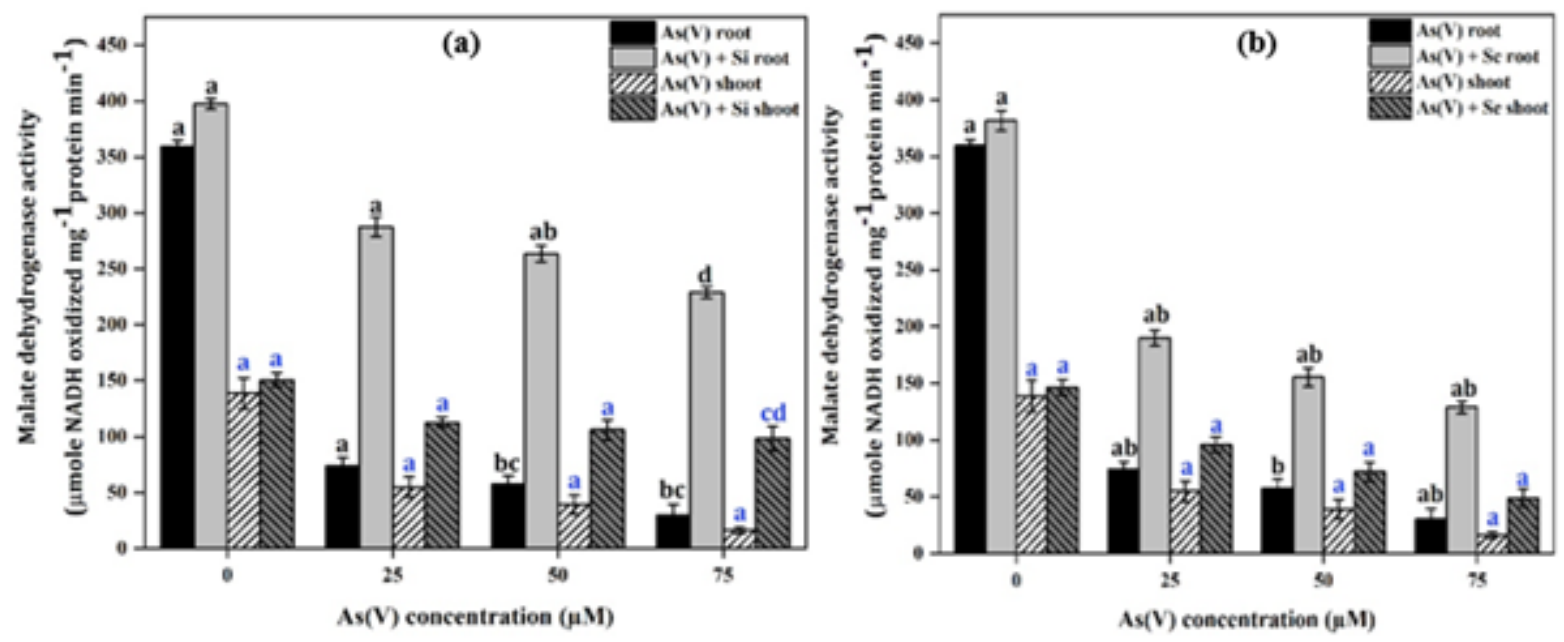

Figure 6

Influence of increasing concentrations of $\mathrm{As}(\mathrm{V})$ with or without Si (a) and Se (b) on MDH activity in 3 weeks old rice seedlings. Different letterings are used to indicate statistically significant treatments differences, at $5 \%$ level of significance, for both roots and shoots separately.
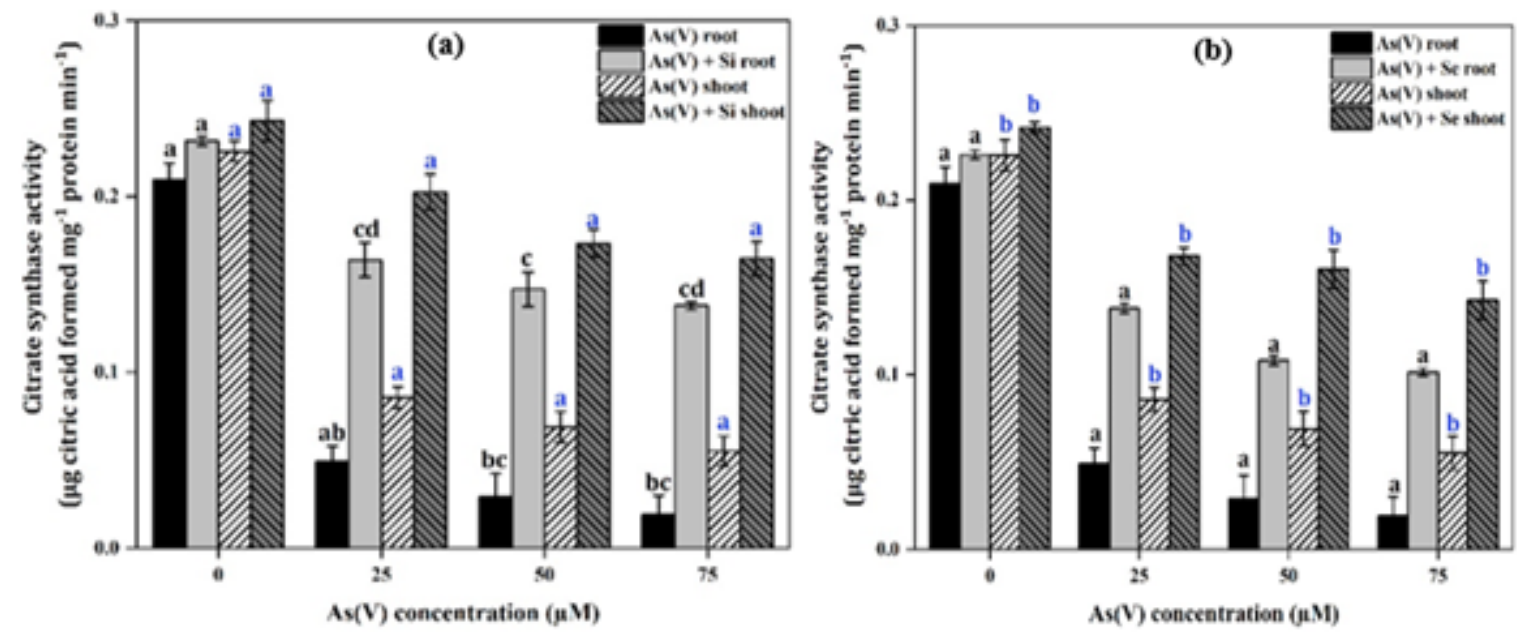

Figure 7

Influence of increasing concentrations of $\mathrm{As}(\mathrm{V})$ with or without Si (a) and Se (b) on CS activity in 3 weeks old rice seedlings. Different letterings are used to indicate statistically significant treatments differences, at $5 \%$ level of significance, for both roots and shoots separately. 

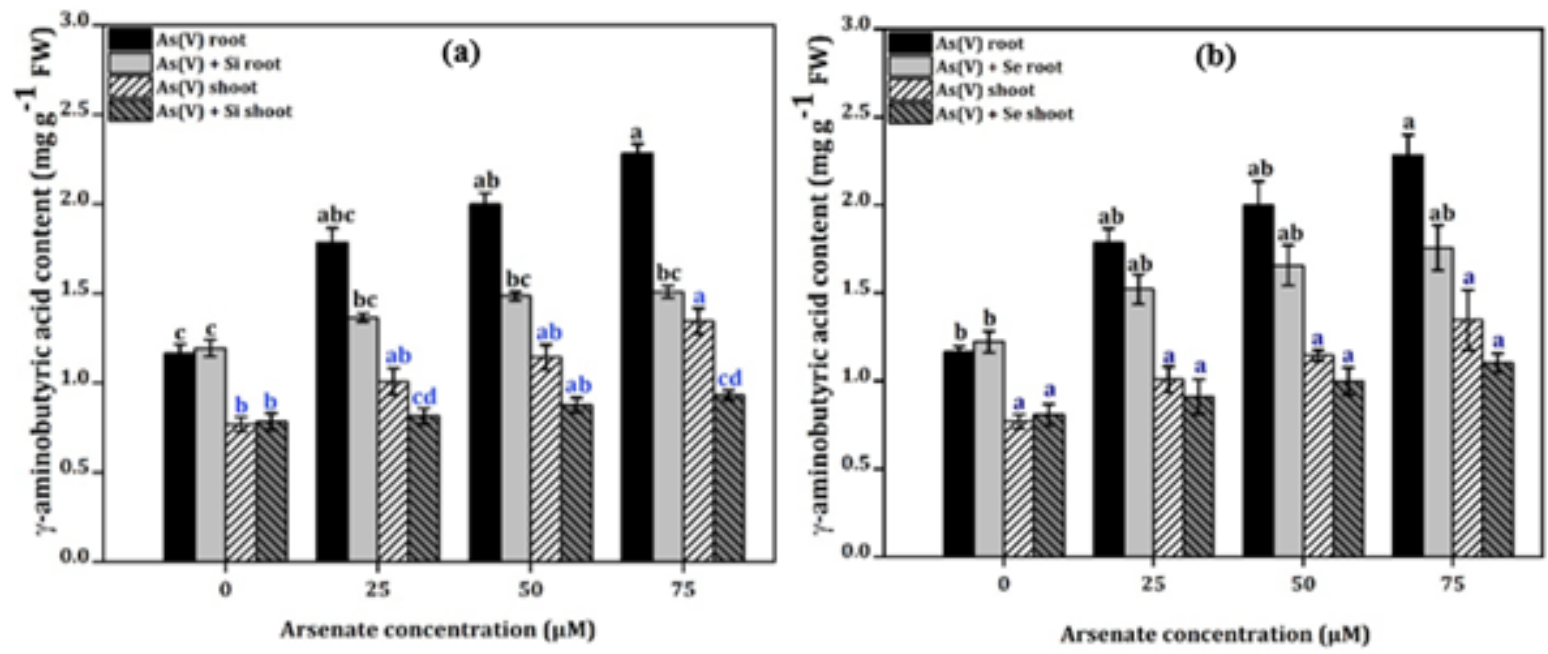

Figure 8

Influence of increasing concentrations of $\mathrm{As}(\mathrm{V})$ with or without $\mathrm{Si}(\mathrm{a})$ and $\mathrm{Se}(\mathrm{b})$ on GABA contents in 3 weeks old rice seedlings. Different letterings are used to indicate statistically significant treatments differences, at $5 \%$ level of significance, for both roots and shoots separately.
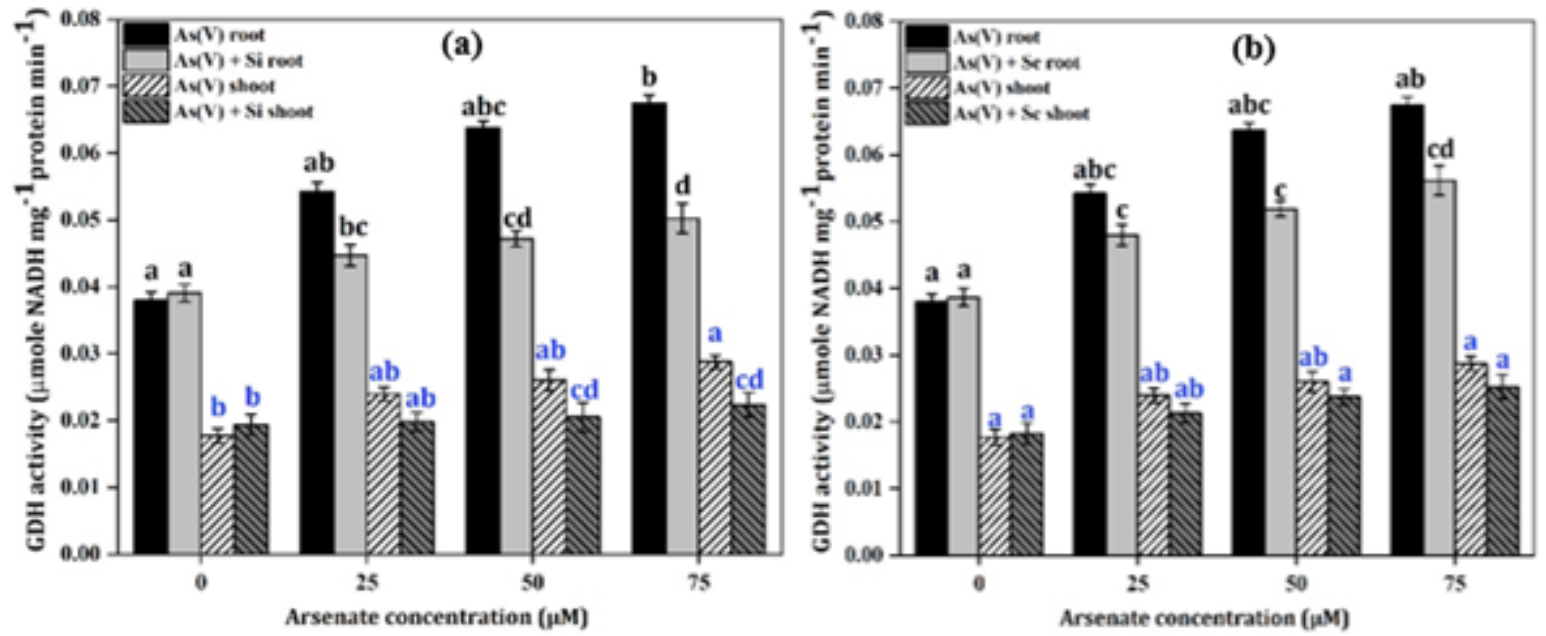

Figure 9

Influence of increasing concentrations of $\mathrm{As}(\mathrm{V})$ with or without $\mathrm{Si}(\mathrm{a})$ and $\mathrm{Se}(\mathrm{b})$ on glutamate dehydrogenase activity in 3 weeks old rice seedlings. Different letterings are used to indicate statistically significant treatments differences, at $5 \%$ level of significance, for both roots and shoots separately. 

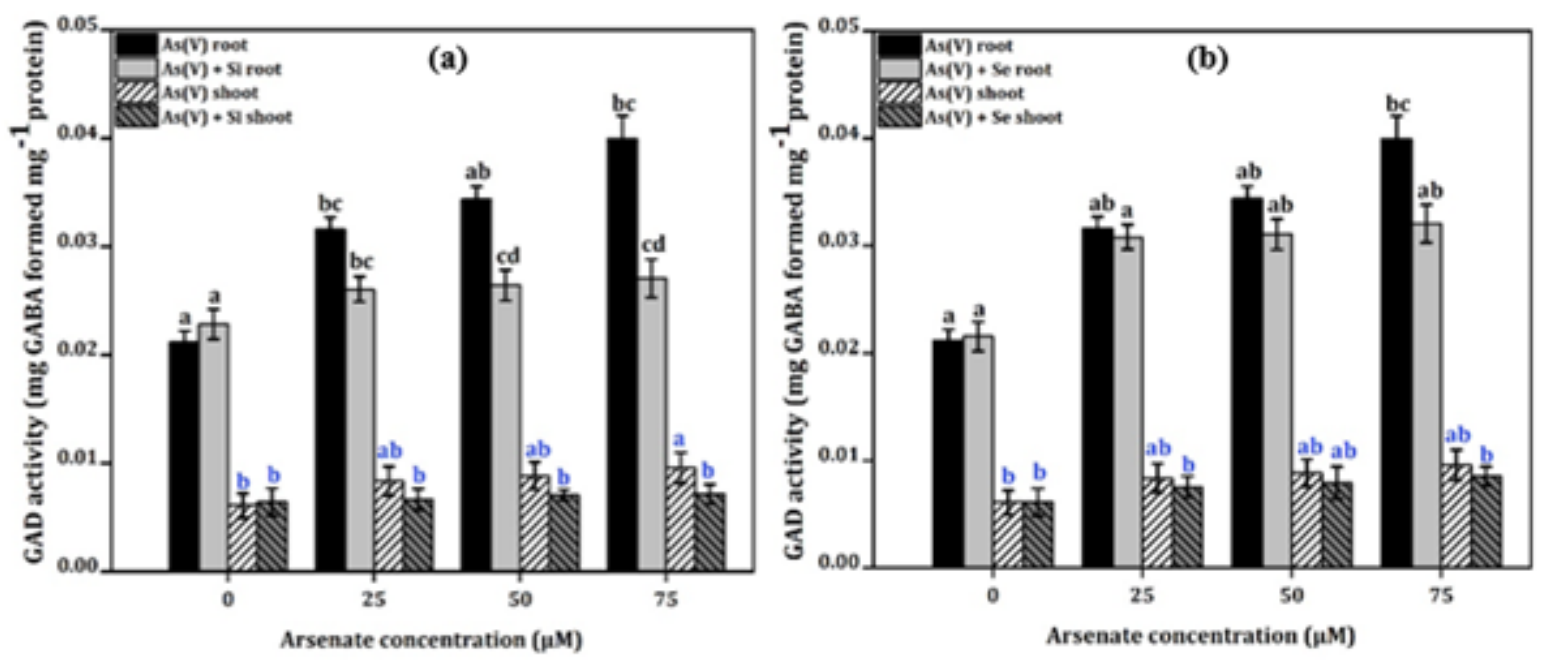

Figure 10

Influence of increasing concentrations of $\mathrm{As}(\mathrm{V})$ with or without $\mathrm{Si}(\mathrm{a})$ and $\mathrm{Se}(\mathrm{b})$ on glutamate decarboxylase activity in 3 weeks old rice seedlings. Different letterings are used to indicate statistically significant treatments differences, at $5 \%$ level of significance, for both roots and shoots separately.
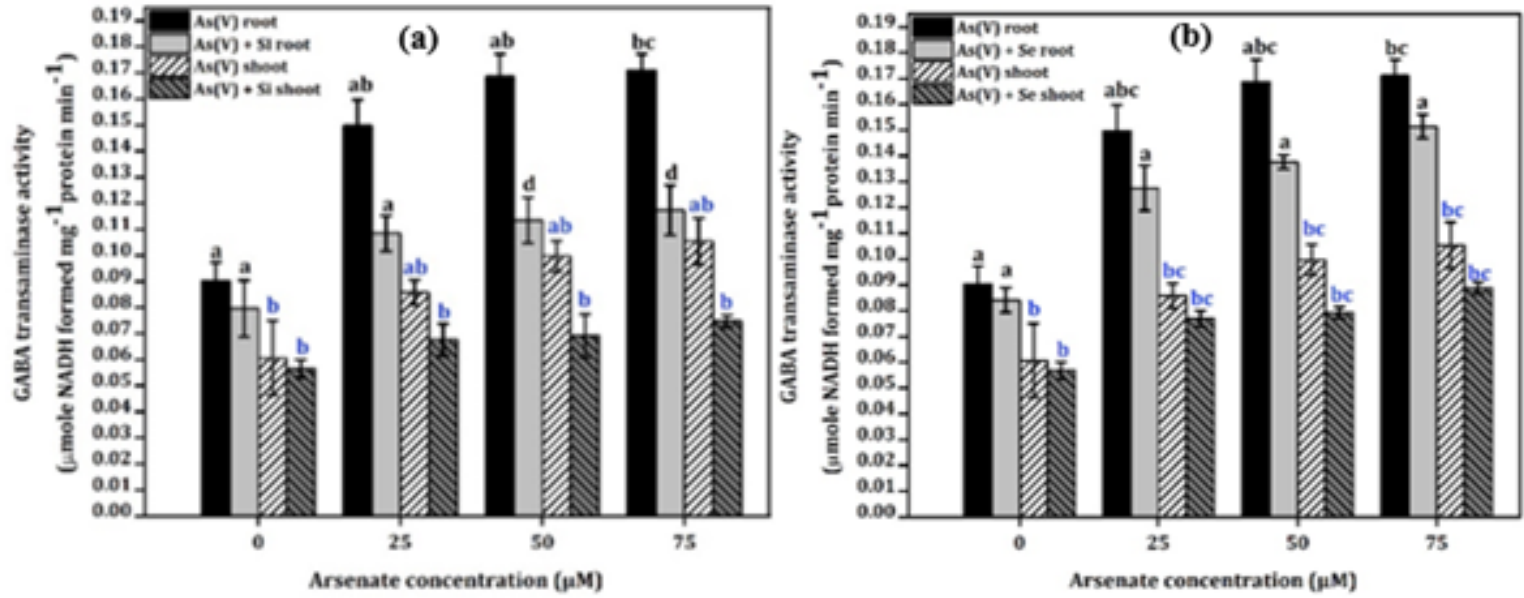

Figure 11

Influence of increasing concentrations of $\mathrm{As}(\mathrm{V})$ with or without $\mathrm{Si}(\mathrm{a})$ and $\mathrm{Se}(\mathrm{b})$ on GABA transaminase activity in 3 weeks old rice seedlings. Different letterings are used to indicate statistically significant treatments differences, at $5 \%$ level of significance, for both roots and shoots separately. 

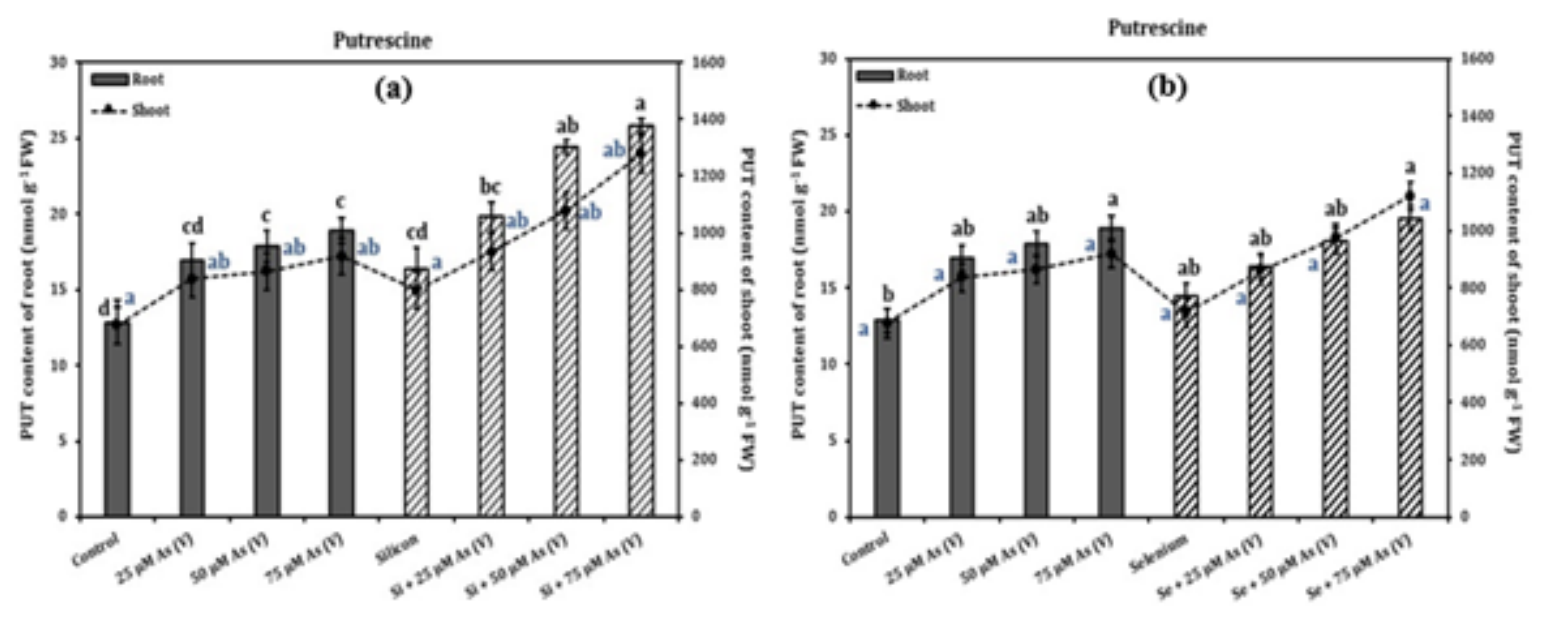

Figure 12

Influence of $A s(V), A s(V)+S i$ and $A s(V)+S e$ on Put contents in 3 weeks old rice (cv. MTU-1010) seedlings. Different letterings are used to indicate statistically significant treatments differences, at $5 \%$ level of significance, for both roots and shoots separately.
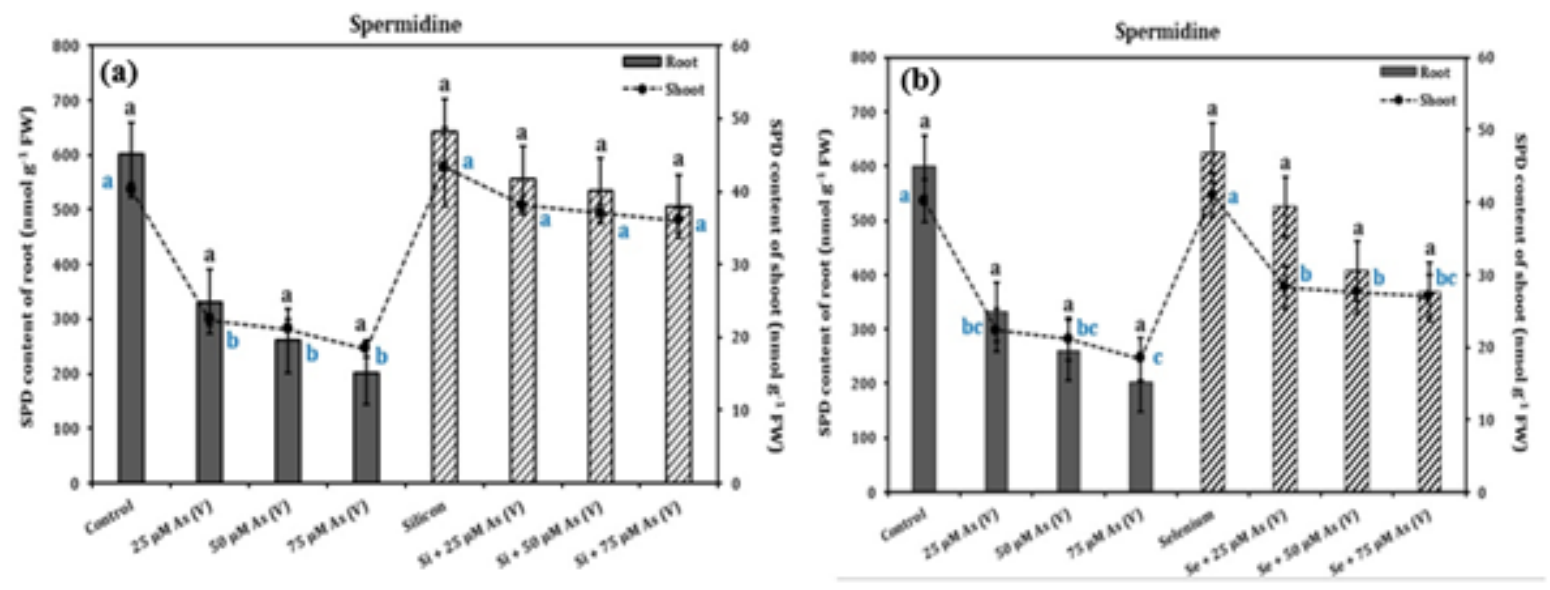

Figure 13

Influence of $\mathrm{As}(\mathrm{V}), \mathrm{As}(\mathrm{V})+\mathrm{Si}$ and $\mathrm{As}(\mathrm{V})+\mathrm{Se}$ on Spd contents in 3 weeks old rice (cv. MTU-1010) seedlings. Different letterings are used to indicate statistically significant treatments differences, at $5 \%$ level of significance, for both roots and shoots separately. 

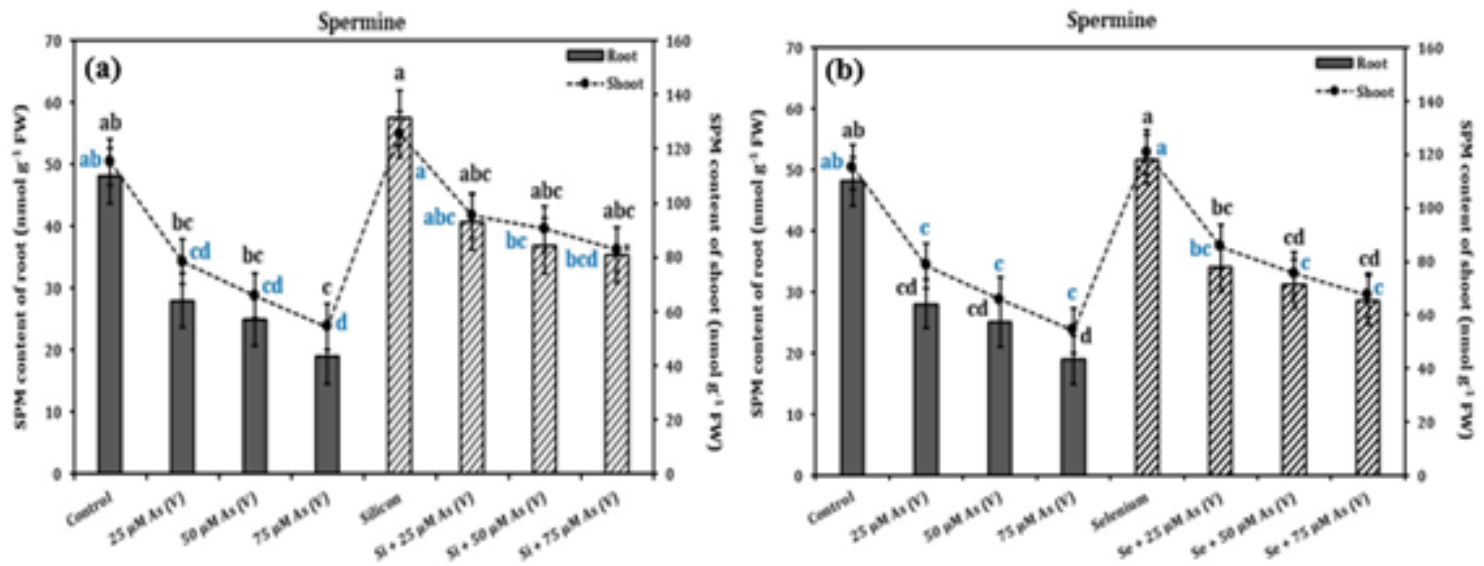

\section{Figure 14}

Influence of $A s(V), A s(V)+S i$ and $A s(V)+S e$ on Spm contents in 3 weeks old rice (cv. MTU-1010) seedlings. Different letterings are used to indicate statistically significant treatments differences, at $5 \%$ level of significance, for both roots and shoots separately.

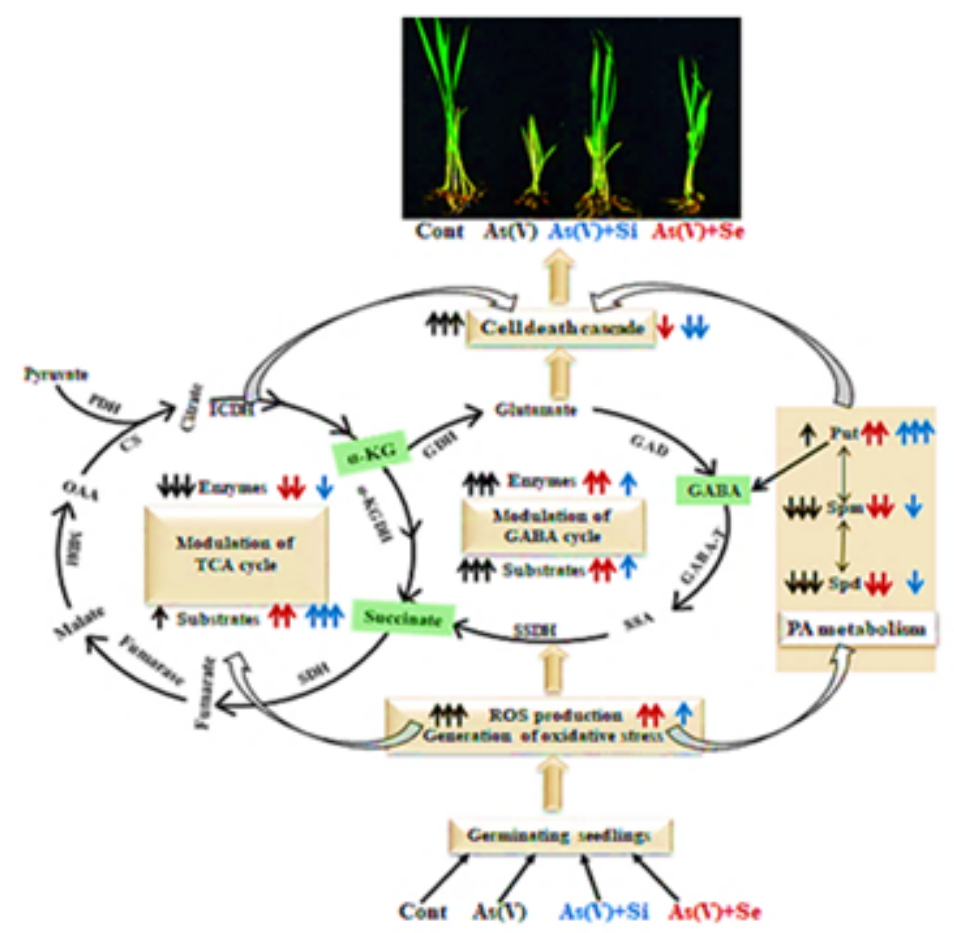

Fig. 15. Overall schemaic representation showing events toward mitigation of arsenic induced toxicity by silicon and selenium on TCA cycle, GABA and polyamine metabolism in 21 days old rice seedlings.

Only Hoagland solution - Cont; Arsenate - As(V); Arsenate + Silicate - As(V)+Si; Arsenate + Selenate - As(V)+Se; Significant alteration $(\uparrow \uparrow / \downarrow \downarrow)$; Moderate alteration ( $\uparrow \uparrow \downarrow)$; Low alteration $(\uparrow \downarrow)$; PDH - Pyruvate dehydrogenase; Cs - Citrate synthase; ICDH - Isocitrate debydrogenase; $\boldsymbol{a}$-KG - $a$-Keto glutarate; $\boldsymbol{a}$-KGDH - $a$-Keto glutarate debydrogenase; SDH - Succinate dehydrogenase; MDH - Malate dehydrogenase; OAM - Oxaloacetate; GAD - Glutamate decarboxylase; GDH - Glutamate dehydrogenase; GABA - gamma-Aminobutyric acid; GABA-T - gamma-Aminobutyric acid transaminase; SSA -Suceinic semialdehyde; SSDH - Succinic semialdehyde dehydrogenase; ROS - Reactive exygen species; Put - Putrescine ; Spm - Spermine; Spd - Spermidine; PA - Polyamine

\section{Figure 15}

See image above for figure legend. 


\section{Supplementary Files}

This is a list of supplementary files associated with this preprint. Click to download.

- Supplementaryfile.docx

- Tables.pdf 